\title{
DEL «FUERO» AL ARRENDAMIENTO. TENENCIA Y EXPLOTACIÓN DE LA TIERRA EN LEÓN ENTRE LA EDAD MEDIA Y LA EDAD MODERNA*
}

\author{
JOSÉ ANTONIO SEBASTIÁN AMARILLA \\ Universidad Complutense de Madrid
}

\section{RESUMEN}

Las relaciones establecidas entre señores y campesinos en torno a la tierra, concretadas en diversas estrategias de gestión y formas de tenencia, constituyen un capítulo central de la historia agraria medieval y moderna de la Corona de Castilla. En este texto se analiza su evolución en el seno de un extenso patrimonio monástico leonés, vinculándola a la de la coyuntura económica y social, entre fines del siglo XII y comienzos del xVI. Su comprensión es imprescindible para entender las pautas de explotación del terrazgo aplicadas en la Edad Moderna y el propio sistema agrario en el que prosperaron.

\begin{abstract}
Landlord-peasant land relationships embodied in different management strategies and forms of possession, constitute a central chapter in the medieval and modern agriculture history of the Castilian crown. In the following text, we analyse its evolution within the extended monastic patrimony of León, connecting it to social and economic circumstances between the end of XIth century and the beginning of the XVIth century. Understanding them becomes

* Expreso mi gratitud, eximiendo de responsabilidad en los yerros, a las siguientes personas, que han leído y criticado distintas versiones de este texto: Isabel Alfonso, Carlos Estepa, Cristina Jular y Esther Pascua, del Departamento de Historia Medieval del Centro de Estudios Históricos del CSIC. Montserrat Durán, Pedro Fatjó, Gaspar Feliú, Gabriel Jover y Enrique Llopis, participantes en el VI Congreso de la Asociación de Historia Económica. Mis compañeros del Grupo de Estudios de Historia Rural, especialmente Domingo Gallego y José Ignacio Jiménez Blanco. Y los informantes anónimos de la Revista de Historia Económica.
\end{abstract}


all the more important since they play a key role in the explanation of exploitation field patterns applied in the modern era and of the agriculture system where they thrived.

\section{INTRODUCCIÓN}

En el ámbito de la historia agraria española, cada vez más estudiosos comparten la necesidad de superar «las vallas que, tradicionalmente, han separado la Edad Moderna de la Contemporánea, a fin de lograr una visión coherente de la evolución de la sociedad rural desde el siglo XviI al $\mathrm{xX}{ }^{1}$. Si ello resulta preciso para un período de tránsito en el que las transformaciones fueron enormes, aún lo es más para otro, entre la Edad Media y la Moderna, donde fueron menores. $\mathrm{Y}$ en cuanto a las relaciones establecidas entre señores y campesinos en torno a la tierra, resulta imprescindible. Consecuentemente, en este texto trataré de esclarecer las raíces medievales de las estrategias de gestión y de las formas de tenencia utilizadas en un patrimonio señorial leonés en los siglos modernos, y de reconstruir su evolución desde el siglo XII.

Hacia 1520, la abadía cisterciense de Sandoval, fundada en 1167 junto a Mansilla, a 20 kilómetros de León, había logrado restaurar su economía tras la difícil etapa bajomedieval, hallándose al comienzo de una fase de prosperidad que perduraria hasta principios del siglo XVII. Dicha restauración estuvo vinculada a una serie de cambios en las estrategias de gestión de su patrimonio -formado por 4.300 hectáreas de labrantíos y pastizales, dispersas por 80 términos del Oriente leonés ${ }^{2}$-, que, iniciada a mediados del siglo XIII, se completó por entonces.

Su culminación, a comienzos del Quinientos, supuso el tránsito a la explotación indirecta de las pocas haciendas que se gestionaban directamente, a cambio de rentas en especie y mediante fórmulas de cesión del usufructo dominadas por los arrendamientos por nueve años o menos. En consecuencia, la renta feudal del cenobio se centró en la renta en productos, relegándose las percibidas en dinero y en trabajo, permitiendo al monasterio aprovechar, hasta fines del siglo, una coyuntura favorable a los perceptores de grano. Luego, pese a las vicisitudes acaecidas entre

1 Saavedra y Villares (1991), ix. Un buen ejemplo lo constituye Jiménez Blanco (1996).

2 Sebastián (1992a), 164-185. Denomino Oriente leonés a la franja de la actual provincia de León definida por las montañas cantábricas al Norte, el meridiano de la capital leonesa al Oeste, y la corriente del Cea al Este y al Sur. 
1600 y 1835 , aquellas estrategias y esta composición, salvo pequeñas modificaciones, sustentaron a la economía monástica hasta la desamortización ${ }^{3}$.

Las formas de cesión del útil de sus fincas empleadas por Sandoval en el siglo xvi pueden ordenarse en dos apartados, los arrendamientos renovables y las cesiones enfitéuticas, generalmente perpetuas, denominadas fueros más veces que foros. Pero las realidades así designadas no poseían los contornos relativamente nítidos que suelen atribuírseles. La mayoria de las cesiones, bien por el complejo vínculo que establecían $\longrightarrow 0$ reconocían existía de antiguo- entre los campesinos y el cenobio, bien por las contraprestaciones estipuladas, concernían a una mixtura de aspectos donde el pago por el usufructo del terrazgo se daba la mano con la satisfacción de cargas en reconocimiento de señorío, según la doble dependencia medieval, por la propiedad dominical y por el dominio señorial ${ }^{4}$.

Un ejemplo lo aporta, entre los arrendamientos, el concertado en 1581 con los vecinos de Villaverde de Sandoval, vasallos de la abadía, que tomaron de mancomún el principal labrantío del coto monástico y los prados anexos, por nueve años, pagando en cada uno 576 fanegas de mediado trigo y cebada, 208 de cebada por los prados, 12 carneros, seis libras de cera, 24 gallinas, 24 carros de paja, 24 sernas «con vuestras personas y carros para traer pan o vino 10 leguas alrededor del Monasterio», 12 carros de leña «traídos del monte del Membrillar con vuestras personas, bueyes y carros» y 12 «sernas personales para meter la yerba» 5 .

Entre los fueros, con su doble sentido - forma de cesión del útil, «bienes cedidos a fuero», y carga que recaía sobre ciertos predios, «el fuero que se paga por...», cabe citar, de un lado, el establecido perpetuamente - «fuero ynfetuosin»- en 1553, a favor del concejo de Castellanos, sobre la antigua granja de Valdeandrino, por 24 fanegas anuales de mediado trigo y centeno. $\mathrm{Y}$, de otro, el abonado por un vecino de Cubillas en 1574, también perpetuo, «en reconocimiento del directo dominio y señorío» de Sandoval sobre la casa en que vivía, de dos gallinas y 20 maravedís al año ${ }^{6}$.

La comprensión de una realidad intrincada como ésta requiere reconstruir su proceso histórico de gestación, aun cuando la documentación dis-

${ }^{3}$ Para todo ello, Sebastián (1992a).

4 Estepa (1989), 162.

5 AHN. Clero, libro 5.196. Amén de 24 condiciones complementarias. El coto, espacio en torno al asentamiento de la abadía, propio de ésta con la jurisdicción privativa, incluía a la aldea de Villaverde desde 1167 .

${ }^{6}$ AHN. Clero, legs. 2.753 y 2.755. 
ponible permita esbozar más hipótesis que certidumbres. Distinguiré, al efecto, tres períodos: el primero, entre 1167 y 1250 ; el segundo, entre 1250 y 1480 , y el último, entre 1480 y 1520 .

\section{1167-1250. LA PROBABLE PRIMACÍA DE LA GESTIÓN DIRECTA}

En esta primera etapa, las estrategias de explotación de Sandoval hubieron de adecuarse a dos perspectivas, la de los estatutos del Císter y la de las características de su dominio en formación. Surgida la orden en el siglo xI buscando una lectura más austera de la regla benedictina que la de Cluny, sus constituciones prescribían la gestión directa del terrazgo, mediante la creación por cada abadía de granjas, atendidas por los propios monjes y por conversos o hermanos legos ${ }^{7}$. Ello requería suficientes conversi y que los monasterios tuviesen plena capacidad para organizar sus entornos rurales, recomendándose su fundación en despoblado. Pero, como en cuanto a las prohibiciones de ejercer el poder señorial o cobrar diezmos, las discrepancias abundaron, al respecto, entre el proceder de cada cenobio y las normas del Capítulo General, la asamblea anual de abades reunida en Cîteaux. Así, Sandoval obtuvo la mayoría de sus posesiones en términos poblados, pasando a controlar un espacio agrario ya organizado en sustitución de los donantes o vendedores ${ }^{8}$. $\mathrm{Y}$, además de no disponer de muchos legos, fue incorporando haciendas que trajeron consigo, frecuentemente, la posibilidad de utilizar la fuerza de trabajo de vecinos de las aldeas inmediatas. Ello dio lugar a una aplicación de la gestión directa mucho más pragmática de lo que preveía el ideal cisterciense.

$\mathrm{Al}$ inicio del siglo XIII, la mano de obra a disposición del monasterio respondía, como en otros casos, a tres conjuntos diferentes ${ }^{9}$. Primero, una mano de obra dependiente, compuesta por numerosos campesinos que, asentados en solares y como vasallos, pasaron a engrosar su dominio ${ }^{10}$. La permanencia de muchas de tales tenencias, ya que la formación de

${ }^{7}$ Frente a una tradición historiográfica que magnifica dicha orientación administrativa, coincido con la crítica realizada por Alfonso (1993).

* Sebastián (1992a), pp. 442-507, y Castán (1977).

9 Para Moreruela, Alfonso (1983), 324, para La Santa Espina, López García (1990), 23, y para Palazuelos, Díez Espinosa (1982). En general, Moreta (1974), 90 y ss., y Ayala (1994), 331 y ss.

${ }^{10}$ En 1210, el cenobio poseía heredades que incluían solares y campesinos dependientes, «cum tota iurisdicione et dominio», en el coto y en 33 poblaciones, y habia recibido la 
granjas y la consecuente reorganización del espacio productivo afectó a pocos predios monacales, supuso el reconocimiento del derecho de usufructo a sus poseedores, pudiendo la abadía exigir ciertas contraprestaciones ${ }^{11}$. Éstas tomarían la forma de prestaciones personales a verificar en los terrenos dominicales que aquélla se reservase. Aun faltando testimonios sobre sernas en los diplomas de Sandoval anteriores a 1250 , su presencia debe juzgarse segura por su racionalidad respecto de una implantación significativa de la gestión directa y por lo sucedido en otros patrimonios eclesiásticos cercanos ${ }^{12}$. Además, la exigencia de sernas sería distintiva de los dominios cistercienses desde la instalación en la península de la orden a mediados del siglo XI, y subsistiría en tierras leonesas más que en otras partes ${ }^{13}$. En segundo lugar, una mano de obra doméstica, integrada, primero, por los conversos. En un diploma de 1235 aparecen «fre Ysidro carpentero; fre Domingo de la cavaleriza; fre Martin zapatero; fre Aparicio del ospital; fre Domingo ferrero; fre Joan del forno; fre Joan de la obra; fre Micael del pison»; y en dos de 1242, «frates Iohannes de la boeria» y «fre Dominico de los cavalos; fre Dominico Pelaez de las oveyas». Y por los propios monjes: la donación de dinero que recoge el texto de 1235 se hizo «par que los monges sean escusados que non sieguen que nos vimos que po los monges que avien per si a segar e non posien cantar sos misas» ${ }^{14}$. Por último, los asalariados temporales, a los que se recurriría esporádicamente, como permitía el Capítulo General desde $1134^{15}$. Conocidos en el entorno de Sandoval, los donantes de 1235 los mencionaban: «por esto diemos nos estos morabitinos, que comprendes en de heredat que per la riendeda que saldra desta heredat que sean sollados mancebos que fagan esta segada».

jurisdicción sobre ocho granjas. Castán (1981), documentos 4, 8, 10, 17, 20 y 22, y Biblioteca Nacional (BN, en adelante), Manuscritos, 712, donación 3.

11 El solar, unidad básica de explotación familiar, sede de la casa y el huerto campesinos, así como tenencia adscrita a dependencia señorial y unidad de percepción fiscal y de renta, se detecta en León desde mediados del siglo XI, difundiéndose en el XII. Ayala (1994), 243-246 y 321-331.

12 Cistercienses, como los de Moreruela y Palazuelos, y ajenos a la orden de San Bernardo pero inmediatos al de Sandoval, como los de Eslonza, Escalada, Sahagún, San Isidoro y la catedral de León. Respectivamente, Alfonso (1983), 325 y ss., Díez Espinosa (1982), 154 y ss., Alfonso (1974), 185 y ss., Rodríguez Fernández (1981), II, 120-126 y 264-267, Moreta (1974), 103, Estepa (1975), 115 y ss., y Fernández Flórez (1985), 221.

${ }^{13}$ Para lo primero, García de Cortázar (1988), 103. Para lo segundo, Moreta (1974), 111, Martínez Sopena (1985), 262, Fernández Flórez (1985), 241, y Ayala (1994), 374-379.

${ }^{14}$ Castán (1981), documentos 62, 65 y 67.

15 Álvarez Palenzuela (1978), 60. 
Tres factores realzan la importancia de la mano de obra dependiente. Uno, la consolidación en tierras leonesas de estructuras feudales antes de erigirse Sandoval ${ }^{16}$, que implicaría la sujeción generalizada del campesinado a sus señores, restringiéndose el colectivo del que saldrían los conversos al de los dependientes del cenobio. Dos, que, en cuanto a la labranza, los freyres legos serían, ante todo, unos «supervisores cualificados» ${ }^{17}$. Y tres, que conforme se extendió en la orden una mentalidad aristocrática, las normas promulgadas en Cîteaux redujeron la aportación al cultivo de los monjes ${ }^{18}$.

En estas condiciones, los bernardos de Sandoval, en esta primera etapa, extendieron la gestión directa adaptándola a su patrimonio fundiario, según las características de cada heredad y la dotación de mano de obra que pudiesen asignar a cada una. Adviértase que, ni la magnitud de aquél, en continuo aumento entre 1167 y 1250 , ni su dispersión, facilitaban tal implantación. Para 1210, varios documentos, en especial la bula pontificia confirmatoria de las adquisiciones del cenobio expedida en ese año ${ }^{19}$, permiten apreciar la organización del dominio y argumentar sobre su explotación. Cabe inferir que la gestión directa dominase en sus centros neurálgicos, el coto monástico y las granjas. Los campos del coto se labrarían mediante las sernas que los vasallos de Villaverde y otras aldeas próximas habrían de satisfacer por sus solares, con el apoyo de los propios regulares. En él, los legos, según el texto de 1235 , sólo desempeñaban oficios dentro del claustro y cuidaban del ganado.

Los conversos participarían en las faenas agrarias en las granjas, unidades orgánicas de explotación ${ }^{20}$ con los elementos necesarios - labrantíos, pastos, bestias de tiro, aperos, construcciones de habitación y almacenamientopara asegurar, con una fuerte tendencia a la autosuficiencia, las labores, aunque dependientes del exterior en cuanto a la mano de obra empleada. Cada freyre granjero rendiría anualmente cuentas, al abad, de la granja que regía y de las heredades cercanas, de las sernas realizadas por los tenentes, de las rentas que hubiesen abonado y de los excedentes obtenidos. En los diplomas de 1235 y 1242 ya citados aparecen varios magistri grangiae, conversos cuyos nombres se registraron seguidos del de la posesión que y 1150 .

${ }^{16}$ Para Estepa (1989), 206, en el siglo XI. Para Ayala (1994), 232-301, entre 1050

17 Como aduce Alfonso (1993), 33 y 36.

${ }^{18}$ Por ejemplo, en 1233; Álvarez Palenzuela (1978), 59.

19 Biblioteca Regional «Berrueta» de León, Sandoval, carp. I, doc. 4.

${ }^{20}$ Tomo esta expresión de García Sanz (1981a), 39-47, y (1981b), 96-107. 
administraban. En uno, «fre Micael de Fontes; fre Gil de Vila Amor; fre Domingo de Nava», y en los otros dos, «frater Andreas de Manselleya» y «Fre Martin de Val de Xan; fre Andreas de Val de Ondrino» ${ }^{21}$. Su labor supondría distinta organización del trabajo según la vinculación existente entre tales explotaciones y las aldeas de su entorno.

La bula de 1210 señala la pertenencia a Sandoval de quince granjas. De ellas, diez se habían recibido como tales ${ }^{22}$, habiendo conocido dos -las de Fuentes de Carbajal y Valdeandrino- una notable ampliación que había permitido al cenobio controlar los dos núcleos en cuyos términos radicaban. Las cinco restantes, al incorporarse, todavía eran lugares ${ }^{23}$. Puede colegirse que, en las más aisladas, los conversos aportasen el grueso del esfuerzo requerido, y que, en las inmediatas a localidades sobre las que Sandoval poseyese prerrogativas, se recurriese a las sernas bajo la supervisión de los legos. No obstante, en cinco de estas últimas, el empeño de los monjes por acrecentar su extensión y reorganizar el espacio agrario a su criterio, la mejor evidencia de su intención de expandir la gestión directa en este período, implicó la despoblación de los enclaves homónimos ${ }^{24}$. Acudiendo al «Becerro de Presentaciones» de la catedral de León como guía de los núcleos poblados en el Oriente leonés hacia $1250^{25}$, se observa que, por entonces, Valdeandrino, Villamoros de Sobarriba, Villamor, Valdellán y Villamoros de Ribaesla ya no lo estaban ${ }^{26}$. Por tanto, la gestión directa de las granjas de Sandoval fue quedando sometida, en la primera mitad del doscientos, a unas restricciones en cuanto a la mano de obra disponible que la hacían muy sensible a cualquier disminución de la doméstica. Y, sobre todo, donde procesos de despoblación privaron a ésta de su sostén, la mano de obra dependiente.

${ }^{21}$ Castán (1981), docs. 62, 65 y 67.

${ }^{22}$ Mansillexa, Fontanilla, Payuelo, La Navilla, Hontoria, Fuentes de Carbajal, Valdeandrino, «Molina Sicca», «Nava de Rege» y «Nechas». Castán (1981), docs. 8, 17 y 20, y Pérez-Embid (1986), 142.

${ }^{23}$ Villamoros de Sobarriba, Valdellán, Villamor, Villamoros de Ribaesla y Palacino. Castán (1981), docs. 10, 11, 14, 15, 26, 32, 35, 42, 51, 53, 54 y 55.

${ }^{24}$ La cual quizá conllevase la conversión en freyres de parte de sus vecinos. Dicho empeño lo demuestra el que Fuentes de Carbajal, Palacino, Valdeandrino y Villamoros de Ribaesla concentrasen la cuarta parte de las donaciones de predios efectuadas a Sandoval entre 1167 y 1250 (muchas de pequeñas divisas campesinas, forzadas unas, remuneradas otras), y casi el 50 por 100 de las compras. Sebastián (1992a), 447-467.

25 Éste, estudiado por Fernández Flórez (1984), 262-565, aunque fechado en 1468, incluye una detallada relación de las iglesias y lugares existentes en la diócesis leonesa a mediados del siglo XIII.

${ }^{26}$ Fernández Flórez (1984), 498. 
El diploma papal de 1210 atestigua que, además, Sandoval poseía heredades en términos de 52 localidades, destacando las referidas a 17 aldeas y siendo menos extensas las concernientes a las 35 restantes. Respecto a su explotación, las obligaciones de la mano de obra doméstica en las granjas y el coto no le consentían una ubicuidad que su magnitud tampoco propiciaba: sólo 20 conversos, junto a 25 monjes, confirmaron el diploma de 1235 varias veces citado, y no parece que la abadía contase con muchos más ${ }^{27}$. Lo más congruente es que dichas heredades fuesen cultivadas por quienes vivían en las aldeas inmediatas. $\mathrm{Y}$ dado que muchas de aquéllas incluían tenencias campesinas además de tierras roturables libres, puede inferirse que las prestaciones personales exigidas por el disfrute de las unas permitiesen la explotación de las otras.

Pero el recurso efectivo a tales servicios de trabajo por parte del monasterio tendría que ver con otros aspectos. La porción de cada hacienda que los monjes se reservasen para su explotación directa dependería, al menos, de la envergadura de aquélla, de la parte ocupada por solares campesinos y de la distancia que la separase de los ejes del dominio. Debe enfatizarse lo último, pues, si se pretendía cultivar los campos mediante sernas, la supervisión de su cumplimiento por los conversi, residentes en el claustro y las granjas, era crucial. Es decir, desde criterios de eficiencia, la imposición de la gestión directa, utilizando mano de obra dependiente, no sería aconsejable en las heredades de menor dimensión, en las que las tenencias ocupasen la mayor parte del espacio y en las más alejadas del coto y de las granjas, por tanto, en casi todas las 35 propiedades de menor fuste. En éstas, su entrega a los lugareños a cambio de un canon en especie o en metálico constituiría la alternativa más razonable ${ }^{28}$. En cuanto a cómo se efectuaron tales cesiones, cabe construir una hipótesis fundamentada.

No existe testimonio de que Sandoval otorgase fueros a las comunidades aldeanas que pasó a controlar ${ }^{29}$. Su falta impide conocer las exacciones que afrontaban sus dependientes, comúnmente recogidas en tales textos normativos. Pese a ello, debieron de quedar sujetos a «hacer fuero». Esta figura, citada por vez primera en un diploma monástico en 1286,

${ }^{27}$ Castán (1981), doc. 62.

${ }^{28}$ De hecho, en 1208, Cîteaux autorizó la cesión a renta de predios «poco útiles». Álvarez Palenzuela (1978), 62.

29 Coherentemente con su escasa necesidad de realizar una intensa labor colonizadora. En cambio, Moreruela promulgó nueve antes de 1250; Alfonso (1983), 343. 
se conocía en León mucho antes ${ }^{30}$. Quizá supusiese en origen la satisfacción por el vasallo de lo exigido en el fuero señorial, pero devino en el censo que, en trabajo, especie, dinero o una combinación de estas formas, debía abonar por el solar que usufructuaba ${ }^{31}$. Así, cualquier campesino asentado en un solar de Sandoval estaría obligado a «hacer fuero», en contraprestación por el útil y en reconocimiento del señorío monástico, asemejándose esta figura a la infurción castellana, expresiones ambas de dependencia territorial y señorial ${ }^{32}$.

Por tanto, cabe suponer que los monjes de Sandoval procurasen que los fueros a satisfacer por sus vasallos en el coto, en las granjas que no hubiesen conocido procesos de despoblación local y en las heredades más grandes cuya incorporación hubiese conllevado otras prerrogativas, tomasen la forma de servicios de trabajo a efectuar en la reserva. En cambio, en las haciendas más pequeñas y distantes, y en las que recurrir a las sernas resultase ineficiente, la cesión de su uso a los cultivadores implicaría conmutar dichas prestaciones por fueros en dinero o especie ${ }^{33}$. Así pues, la gestión directa debió de introducirse en el dominio de Sandoval con una notable aportación de las sernas y con una intensidad diversa, máxima en el coto y en las granjas, pero variable, según su magnitud y cercanía, en el resto de las haciendas. En suma, aun bajo su primacía, estaríamos ante un sistema flexible, en cuyo seno convivían diversas formas de explotación del terrazgo. Luego de 1210, parece que dicho modo de gestión perdió vigor en Sandoval, aunque ello sólo se aceleraría después de 1250 . $\mathrm{Al}$ efecto, deben considerarse las transformaciones atinentes a otros dominios de la zona, a la composición de la renta feudal de los cistercienses y a su propio entorno rural.

En varios patrimonios eclesiásticos leoneses, la gestión directa ya había retrocedido hacia 1200 , al optar sus gestores por la recepción de rentas,

${ }^{30} \mathrm{El}$ abad aludía en ese año a «todos los fueros que nos y emos de aver de los vasallos et de la eglesia» en Roderos; Castán (1981), doc. 80. La primera referencia documentada por Ayala (1994), 256, data de 1061.

${ }^{31}$ En 1284, el fuero de Algadefe y Santa Marina, lugares de Eslonza, recogía los «fueros»: «Dos omhes a binar e a azar, dos a sembrar e dos a segar e dos a maiar pan del monesterio e uno a podar las uinas e dos, el uno a trillar una trilla de pan... e sennos dineros de cada cassa por los arcos de las cubas». Rodríguez Fernández (1981), II, 265.

32 Alfonso (1983), 336; García de Cortázar (1988), 111; Gautier-Dalché (1965), 101; Estepa (1975), 113, y (1989), 240-241; y Álvarez Borge (1996), 310-318.

33 Sobre la conmutación de semas en el seno del fuero, Alfonso (1983), 336 y ss. 
estrategia que se afianzaría en el siglo XII ${ }^{34}$. Respecto a las casas del Císter, aunque se resistiesen a ello, otros factores actuaban en la misma dirección. Uno de los más relevantes hubo de ser la creciente importancia de los componentes de su renta feudal ajenos al cultivo directo de la tierra, como el cobro de diezmos, el desarrollo de la actividad pecuaria y la propia recepción de rentas por la cesión de predios marginales.

En cuanto a lo primero, Sandoval, hacia 1250, estaba en situación de ingresar anualmente notables cantidades de productos agrarios mediante la percepción de diezmos. Para entonces, pese a las prohibiciones capitulares al efecto ${ }^{35}$, el cenobio había adquirido derechos de presentación sobre 21 parroquias de otros tantos lugares, que le facultaban para participar en sus cillas ${ }^{36}$. Es probable, pues, que, durante el siglo xill, el volumen de productos así allegado contribuyese significativamente, y a menor coste que la explotación directa, al sustento de la familia monástica y al acopio de un excedente comercializable, restando incentivos a la continuidad de aquélla.

En lo tocante a la ganadería, la incorporación al dominio de extensiones de pastos suficientes para sostener un nutrido contingente pecuario indica que los monjes le prestaron mucha atención. Junto a los amplios pastizales del coto, destacan varias adquisiciones efectuadas entre 1180 y $1231^{37}$. Sandoval recorrería dos de las tres etapas que se han detectado, al efecto, entre las economías monásticas del valle del Duero en el siglo xIII ${ }^{38}$ : se hizo con abundantes pastos y, quizá, articuló una trashumancia de corto recorrido entre sus distintas posesiones, pero no consiguió exenciones fiscales que permitiesen a sus rebaños pastar sin cargo en otros puntos del reino, desarrollando una trashumancia auténtica ${ }^{39}$. En cualquier caso, el aumento plausible de la actividad ganadera también actuaría en detrimento

${ }^{34}$ Monasterios como Vega y Sahagún ya habían cedido, en 1207 , prioratos completos. Martínez Sopena (1985), 264 y ss., Estepa (1989), 246-248, y (1993). En general, García de Cortázar (1988), 104.

${ }^{35}$ El Capítulo General, desbordado por los acontecimientos, levantó el veto en 1230. Pérez-Embid (1986), 194.

${ }^{36}$ Castán (1981), docs. 8, 10, 20, 26, 53-55, $57-59$ y 64, y AHN. Clero, carp. 1.000, dip. 15 y leg. 2.752.

${ }^{37}$ En el alto interfluvio Porma-Esla, los montes de Corrales y Juncosa, las granjas de «Fuinas», Hontoria y Membrillar, Valsemana, Isoba, el valle de «Fonte Amoso» y una dehesa en el valle de Hontoria. En el interfluvio Esla-Cea, dos predios y una dehesa en Valdellán, pastos y majadas en otras seis aldeas, y diez majadas entre Valdeandrino y Soto Sajambre. BN. Manuscritos, 712, donaciones 3 y 19, y Castán (1981), docs. 11, 13, 15, 17, 20 y 59.

38 García de Cortázar (1988), 113-114.

39 Dispensas que lograron otras casas de la orden. Entre 1158 y 1254, Valbuena, Huerta, 
de la gestión directa del espacio cultivado. En lo concerniente a las cesiones de pequeños predios, es posible que aminorasen el empeño de los monjes por extender dicho método de explotación, como lo harían, en la década de 1240 , las heredades recibidas mediante donaciones con reserva de usufructo, que incluían la división de dominios ${ }^{40}$.

Por último, en lo referente a su entorno rural, otros obstáculos entorpecieron después de 1210 el desarrollo de la gestión directa. Acaso el reclutamiento de conversos se hiciese más difícil, como ocurrió en otros dominios ${ }^{41}$, quizá por las oportunidades de promoción social que los campesinos percibiesen en otras partes, como las villas del camino francés, próximo a Sandoval o los territorios abiertos a la colonización en el Sur desde 1212. Bastaría, en todo caso, con el estancamiento del personal doméstico que controlaba el cumplimiento de las sernas, aún significativo en 1235, para debilitar la expansión de la gestión directa en un patrimonio que seguía creciendo: de 1210 a 1251, las haciendas relevantes, ajenas al coto y a las granjas, pasaron de 17 a 26 , y las menores, de 35 a $40^{42}$. Lo cierto es que las concentraciones patrimoniales a partir de granjas citadas antes, menos la de Villamoros de Ribaesla, aún ampliada en 1230 , se cerraron al poco de 1210 - la de Valdeandrino en 1209, la de Palacino en 1213, la de Fuentes de Carbajal en 1215 - y no se iniciaron en otras partes ${ }^{43}$. Con independencia de sus motivos, la dirección del fenómeno fue refrendada por el Capítulo General en 1224, cuando extendió a cualquier heredad el permiso concedido en 1208 para ceder el útil de las menos rentables ${ }^{44}$.

En suma, en el dominio de Sandoval, entre 1210 y 1250, la coexistencia de diversos modos de explotación del terrazgo bajo la primacía de la gestión directa fue modificándose en contra de ésta. El aludido diploma de 1235, considerado en su integridad, permite apreciar un punto intermedio de tal evolución. En él, Pedro Muñoz de Villasinda y su mujer, viendo que los monjes descuidaban sus deberes religiosos por participar en la siega

Herrera, Bujedo, Palazuelos y Valdeiglesias; entre 1254 y 1293, Nogales y Castañeda. Pérez-Embid (1986), 176, 203 y 316.

40 En 1245, 1248 y 1249. AHN. Clero, leg. 2.752, y Castán (1981), docs. 68 y 74. Baste un ejemplo. En 1248, Andrés y su esposa María donaron al monasterio siete tierras ubicadas en Villasinda y Valdesaz, pero «que mietre fur nuestra vida de anbos que vivamos en elo en prestamo», pasando a su muerte a aquél.

${ }^{41}$ Alfonso (1993), 20, se muestra crítica con el papel central tradicionalmente asignado, para explicar el retroceso de la administración directa en los dominios cistercienses, al declive de la captación de freyres.

42 Castán (1981), docs. 57, 59, 62, 63, 64, 68 y 75, y AHN. Clero, carp. 1.000, dip. 15.

${ }^{43}$ Castán (1981), docs. 45, 55 y 56, y AHN. Clero, carp. 1.000, dip. 15.

44 Álvarez Palenzuela (1978), 62. 
del coto, donaron al abad 400 «morabitinos» para que comprase un predio $y$, con la renta que produjese, contratase segadores que realizasen dicha labor. A cambio, el abad les otorgó 400 «moravinadas de heredat» en Villaturiel para que las disfrutasen de por vida ${ }^{45}$.

Se trata de un tipo de prestimonio ${ }^{46}$, en el que se aprecia, uno, la excepcionalidad del recurso a asalariados, quizá por su coste, incluso cuando las labores agrícolas requerían más fuerza de trabajo, prefiriendo los monjes atender ellos mismos esa necesidad. Dos, la normalidad con que se aceptó que la heredad comprada produjese una renta, acaso en metálico si se pretendía «asoldar mancebos» de inmediato. $Y$ tres, la importancia atribuida a la operación, quizá la primera de estas características, que fue refrendada por la comunidad en pleno. En definitiva, a la altura de 1235, aun con la coartada de contratar más brazos que facilitasen la explotación directa del coto, dos heredades, la cedida en préstamo y la adquirida, escaparon a la misma. La gestión directa, aun conservando importancia, se batía en retirada.

\section{1250-1480. LA EXTENSIÓN DE LA EXPLOTACIÓN INDIRECTA POR CAMINOS DIVERSOS}

En el dominio de Sandoval, las transformaciones mencionadas se extendieron entre 1250 e inicios del siglo xv. Contribuirían a ello factores citados, como la aportación creciente a su renta feudal de la ganadería y de la percepción de diezmos ${ }^{47}$. Pero su principal catalizador sería la instalación de tendencias depresivas en la zona, como en el resto de la Submeseta Norte, desde mediados del Doscientos, y su profundización en el siglo XIV.

Aunque ignoramos muchos detalles, lo que sabemos sobre la trayectoria de la economía castellana en la segunda mitad del siglo XIII apunta en

45 «Por esta almosna et por otros beneficios et por otros servitios que vos nos feciestes otrorgamos a vos e a vestra muler plenno servitio, que asi fagamos por vos como por uno de nostros companeros». Castán (1981), doc. 62.

${ }^{46}$ Aquel en que la cesión de una hacienda, luego de la entrega de la misma u otra por quien la recibía, se hacía a una persona acomodada (como demuestra la cuantía de la donación), con la obligación, siquiera implícita, de defenderla, entrañando la participación en los bienes espirituales del monasterio y sin establecer una renta. García de Valdeavellano (1955), 71. También, Martínez Sopena (1985), 267 y ss., Ríos (1993) y Jular (1997).

${ }^{47}$ A las 21 parroquias sobre las que Sandoval ejercía derechos en 1250 , se añadieron otras 12 entre 1262 y 1439. Castán (1981), doc. 78, BN. Manuscritos, 712, donaciones 15 y 16, y AHN. Clero, carps. 995, dip. 13, y 1.000, dip. 16, y legs. 2.741, 2.750 y 2.752. 
una clara dirección. Destacan los testimonios sobre la vigencia de una grave crisis agraria en el interior castellano entre 1255 y $1262^{48}$, el detenimiento de la repoblación de la Andalucía Bética, en 1264-1266, en la que el protagonismo de castellanos viejos y leoneses había sido relevante ${ }^{49}$, y el asentamiento, hacia 1290, de la depresión en la cuenca del Duero, donde, al descender la densidad demográfica, la reducción de la mano de obra provocaría un retroceso del área cultivada y un laboreo menos intenso ${ }^{50}$. La disminución de la producción agrícola alimentaría una notable alza de precios, atizada por las manipulaciones monetarias debidas al poder regio ${ }^{51}$. Así, cuando en 1277 Alfonso X perdonó a los leoneses las penas impuestas por dehesas y cañadas labradas, estaría confirmando el fin de la expansión agrícola origen de tales acciones 52 .

Puede ser exagerado vincular exclusivamente tal panorama a una potente corriente emigratoria hacia el Sur, en seguimiento del avance militar que, desde 1212 , había abierto a la colonización enormes espacios ${ }^{53}$. Pero aunque otros factores coadyuvasen a la contracción, como el propio esfuerzo en hombres y dinero durante las grandes conquistas (1225-1248), y el aumento de la carga fiscal regia entre los reinados de Fernando III y Alfonso $\mathrm{X}^{54}$, no debe desecharse dicha correlación. En tierras leonesas, sería relevante una pérdida demográfica equivalente, entre 1225 y 1266, a entre seis y diez veces la población de la ciudad de León al inicio del siglo XIII ${ }^{55}$.

La onda depresiva se afianzaría en el siglo XIV, agravándose la escasez de mano de obra tras el impacto de la peste, mientras que los precios de los productos agrarios, en términos reales, acusaban la acentuada caída

\footnotetext{
48 Aguadé (1988).

49 González Jiménez (1995), 223.

${ }^{50}$ García Sanz (1981c), 89-94.

"1 Ruiz (1981), 22-29.

52 Martín y Álvarez (1982), 32.

53 García de Valdeavellano (1968), 262, expuso esta tesis. Ruiz (1981) la formuló de modo más radical.

54 González Jiménez (1995), 221, Ladero (1982), 16 y ss., y Aguadé (1988), 369.

"He hecho esta estimación a partir de datos aportados por González Jiménez (1995), 215-217. Éste, tras cifrar entre 120.000 y 200.000 los castellano-leoneses que afluyeron, de 1225 a 1266, a los reinos de Jaén, Córdoba, Sevilla, Badajoz y Murcia, considera representativa, respecto a la proporción de leoneses en tales cifras, su participación estimada en el repartimiento de Sevilla, en 1248-1253 (un 14 por 100), y en la repoblación de Jerez de la Frontera, en 1264 (un 15,3 por 100), por lo que cabría situarla entre 18.000 y 30.000 individuos. Es decir, entre seis y diez veces los 3.000 habitantes con que contaría la ciudad de León en 1200, según Estepa (1977), 140.
} 
de la demanda y los granos, especialmente, afrontaban una evolución desfavorable de sus términos de intercambio ${ }^{56}$. La despoblación de aldeas, advertida ya en $1288^{57}$, adquiriría especial importancia. Según mis cálculos, sobre un conjunto de 178 lugares existentes en el Oriente leonés hacia 1250 según el «Becerro de Presentaciones», 50, el 28 por 100, había desaparecido en $1591^{58}$. Considerando que este proceso no vino acompañado de una relevante concentración del poblamiento en la zona, ni siquiera de 1430 a 1580 , y el crecimiento demográfico habido entre esas fechas, cabe equiparar tales despoblados a un descenso de la población vigente hasta comienzos del siglo $\mathrm{Xv}^{59}$.

Desde mediados del Doscientos, por tanto, Sandoval afrontaría un descenso de la mano de obra disponible que pondría en cuestión la continuidad de la explotación directa de sus heredades. La reducción del número de conversos ${ }^{60}$ implicaría, aparte de menos trabajadores cualificados, graves problemas para controlar las sernas efectuadas por los vasallos, mientras que la carestía de los asalariados aconsejaría obviar su empleo. El cultivo de sus predios hubo de quedar cada vez más ligado a los dependientes que habitaban en sus cercanías, siendo preciso que los monjes reforzasen sus vínculos con ellos, pero ofreciendo condiciones ventajosas que restasen atractivo a alternativas como la emigración. Para ello, Sandoval, intensificando dos procesos en marcha, disminuyó la carga que suponían las sernas y allanó el acceso de los cultivadores al usufructo de sus haciendas. Así pues, entre 1250 y 1400 , la propia evolución de la coyuntura favoreció el avance de la explotación indirecta en su dominio. Dentro de la misma dinámica intervendrían otros factores, como la creciente violencia feudal, acorde con la caída de los ingresos nobiliarios por la crisis, que propició que los monjes pusiesen sus bienes bajo la tutela de seglares, y el impacto de la depresión sobre los ingresos monacales, que alentó, en ocasiones, la cesión a terceros de su recaudación, para allegarlos por anticipado.

56 Valdeón (1985).

${ }^{57}$ El sínodo leonés de ese año aludió a «eglesias despobladas de XX annos aca». González Jiménez (1995), 218.

${ }^{58}$ Fernández Flórez (1984), y Archivo General de Simancas. Dirección General de Rentas, Inv. 24, leg. 1.301.

59 En 1591, la población de villas como Sahagún, Mansilla, Valencia de Don Juan y Mayorga sólo era un 4 por 100 mayor que la de 1526-28. AGS. Dirección General de Rentas, Inv. 24, leg. 1.301, y Contadurías Generales, leg. 768. León, por su parte, apenas superaba los 5.000 habitantes estimados para 1300 por Estepa (1977), 145.

(6) Aludidos por última vez en 1242. En Moreruela lo fueron en 1256 y, en Carracedo, en 1283; Alfonso (1983), 328, y Pérez-Embid (1986), 242. 
Por tanto, los cambios introducidos en la gestión del patrimonio monástico desde 1250 seguirían caminos diversos, sobre los que pueden construirse hipótesis razonables ${ }^{61}$. Uno, constituido por la cesión parcelada de heredades a sus vasallos, o a cultivadores que así pasaron a serlo, para evitar su abandono, más costoso para unos campesinos cuyas tenencias se habían engrosado, y para asegurar su laboreo tras la pérdida de eficiencia de las sernas. Otro, afecto a haciendas extensas, que, desde el prestimonio, detectado ya en 1235, iría hasta la encomienda, en cuyo caso las cesiones retribuirían servicios de protección. Y otro, en el que la necesidad acuciante de ingresos anticipados llevaría a interponer mediadores entre la abadía y sus dependientes, que, por recaudar las rentas, adelantarian a aquélla un tanto alzado; éste se bifurcaría en dos direcciones: una, también hacia la encomienda, y otra, hacia el empeño de algunas posesiones e, incluso, su trueque por dinero. Obviamente, un proceso de cesión tan complejo, desarrollado durante más de siglo y medio, ni afectó por igual a todas las posesiones del cenobio, ni acabó rápidamente con la explotación directa. Conviene distinguir, pues, entre lo ocurrido en el coto monástico, en las granjas y en las heredades.

\subsection{El coto monástico: su permanencia en gestión directa}

Éste, base del aprovisionamiento del cenobio, quedaría fuera de dicho proceso. En su caso, la capacidad de control de los monjes no habría disminuido, siendo aún viable el recurso a prestaciones personales y la concentración en sus labores de los pocos domésticos disponibles.

En efecto, existen indicios de que la gestión directa prosiguió en el coto hasta el siglo xv. Junto a la subsistencia en él de formas de renta-trabajo que alcanzaron la Edad Moderna, destaca la pugna que Sandoval sostuvo en el siglo XIV con el concejo de Mansilla por las inmunidades de sus vasallos que habitaban en aldeas de la villa. El conflicto tuvo por objeto la exoneración fiscal de éstos ${ }^{62}$, incómoda para Mansilla por el alza de la carga fiscal, mostrando la creciente competencia entre la abadía y el concejo por su fuerza de trabajo, por dirigirla a la labranza del coto o a las obras de fortificación de la villa, urgentes conforme se extendían

${ }^{61}$ Según lo advertido por otros estudiosos, como Garcia de Cortázar (1988), 104 y ss., y Estepa (1993).

${ }_{62}$ En 1185, Fernando II había eximido de numerosos tributos a los vasallos de Sandoval. Castán (1981), doc. 19. 
las banderías nobiliarias ${ }^{63}$. En 1308 , una sentencia arbitral obligó a pagar a los referidos vasallos la moneda forera y seis maravedís por cabeza en tiempo de guerra para defensa de la villa, y al concejo, a refrendar su exención tocante a otros impuestos. El cenobio transigió por su interés en atraer cultivadores al coto, pues el concejo permitió que aquellos de sus vasallos vecinos del alfoz que quisiesen, se trasladasen a aquél con todos sus bienes ${ }^{64}$. Más tarde, al acentuar la peste el declive demográfico del Oriente leonés, la merma de contribuyentes propició nuevas presiones de Mansilla. Sandoval recurrió a Enrique II y obtuvo, en 1376, el derecho a elegir de entre los vasallos de fuera del coto diez excusados de tributos que trabajasen en él ${ }^{65}$.

No obstante, a fines del siglo, el cultivo del coto debió de reducirse al mínimo. Mansilla volvió a la carga y forzó un compromiso, en 1397, más favorable a sus intereses que el de 1308, logrando que los monjes pagasen 12 maravedís por cada excusado escogido en su territorio ${ }^{66}$. Y Villaverde de Sandoval casi se despobló ${ }^{67}$. Los monjes ensayaron una nueva forma de reclutar trabajadores, trasunto de la antigua recepción de conversos: la incorporación como donados de matrimonios vecinos de lugares cercanos, que entregaron al cenobio «sus cuerpos, almas y bienes muebles y raíces», tras comprometerse éste a mantenerlos de por vida, y pasaron a habitar en el coto ${ }^{68}$. Entre esta repoblación al inicio del siglo XV y la década de 1480 , cuando comenzaron a arrendarse porciones del coto, faltan noticias, aunque es probable que la gestión directa siguiese prevaleciendo, ocupándose de las labores los excusados -Enrique IV confirmó a Sandoval el privilegio de elegir doce fuera de su término en 1459 - y el restablecido vecindario de Villaverde.

${ }^{63}$ Desde 1288, Mansilla sustituyó el tapial de su cerca por muros de piedra y torres de sillería. Cada aldea del alfoz se encargó de un lienzo de muralla y del tramo de foso correspondiente, obligándose a realizar, en adelante, las facenderas precisas para mantenerlos en buen estado. Ello no evitó que la villa fuese saqueada por una hueste nobiliaria en 1322. Gutiérrez González (1995), 162, Martínez Sopena (1989), 132, y Fernández Catón (1978), 56.

64 AHN. Clero, carp. 995, dips. 9 y 10.

63 Juan I lo confirmó en 1379 y Enrique III lo amplió a doce excusados en 1392. AHN. Clero, leg. 2.745.

66 Encareciendo la mano de obra en un momento de profunda debilidad de Sandoval. AHN. Clero, leg. 2.744.

${ }^{67}$ En 1404, el concejo convocado por el abad no pudo celebrarse por no haber vecinos. AHN. Clero, leg. 2.750.

6onstan cuatro casos entre 1401 y 1407. AHN. Clero, carps. 998, dips. 1 y 18, 999 , dip. 6, y leg. 2.750 . 


\subsection{Las granjas: diversas estrategias de gestión según condiciones específicas}

El cambio de coyuntura iniciado hacia 1250 afectaría de otro modo a las granjas de Sandoval. Su carácter de unidades orgánicas de explotación, adquirido a veces a costa de la despoblación de núcleos vecinos, había ligado su aprovechamiento a la presencia de domésticos. Su disminución las expondría al abandono y a la usurpación nobiliaria, siendo su defensa urgente y complicada. La estrategia adoptada por los monjes obedecería, en cada caso, al distinto alcance de tales contingencias.

Cabe mencionar, primero, tres conjuntos de granjas con trayectorias relativamente claras. Uno, el de las próximas al coto - Malateria, Fontanilla, Mansillexa y Villamoros de la Sobarriba-, que quizá siguiesen un derrotero similar, aunque no puedo afirmar que la explotación directa fuese su única forma de gestión entre 1250 y $1500^{69}$. Otro, formado por Payuelo, Fuentes de Carbajal, Palacino y Villasinda, al que se aplicó el expediente utilizado con las heredades: ubicadas en términos poblados en los que el monasterio poseía solares y vasallos, fueron divididas en lotes y cedidas a estos últimos. $\mathrm{Y}$ otro, integrado por algunas acaso peor situadas, que acabaron desgajándose del dominio, trocándose por otras posesiones y por un dinero cada vez más necesario para Sandoval ${ }^{70}$.

Lo acaecido con las demás granjas es más oscuro aunque, al parecer, no se subdividieron, alcanzando íntegras la Edad Moderna. En cuanto a su gestión, deben distinguirse por el tipo de aprovechamiento dominante. Así, en las de neta vocación pecuaria - Valdellán, Membrillar, Valsemana e Isoba- debió de prevalecer su utilización por los ganados monacales. Desaparecido el cultivo en su seno y yermos los núcleos vecinos ${ }^{71}$, su tránsito a espacios forestales implicó que perdiesen identidad; en el Quinientos, Valsemana incluía las granjas de Hontoria y «Fuinas», Corrales y los montes de Juncosa, y Valdellán, el despoblado de Oques. La labranza

${ }^{69}$ Pero, en 1402, residían donados en la de Villamoros de la Sobarriba y, en 1405 , en Mansillexa. AHN. Clero, carp. 998, dip. 7, y legs. 2.749 y 2.753.

70 «Nechas», permutada en 1318 por diversos predios y 10.000 maravedís para que el cenobio saldase sus deudas. «Molina Sicca», trocada en 1336, por diversos bienes en Villarroañe, Valencia de Don Juan, León y Valdesaz. Y «Nava de Rege», cedida en una fecha desconocida del siglo XIV. AHN. Clero, carp. 995, dip. 13, y leg. 2.752.

${ }^{71}$ Al menos, Corrales, Oques, Valdellán y Membrillar. AHN. Clero, carp. 997, dip. 15, y lib. 5.172. 
sólo reapareció en el siglo xvi; Valdellán se repobló, y sus vecinos arrendaron las nuevas labores; en Valsemana, lo hicieron concejos comarcanos ${ }^{72}$.

Por último, aquellas granjas en las que prevalecía el cultivo - La Navilla, Valdeandrino, Villamor, Valdefresno y Villamoros de Ribaesla - tendieron a cederse en bloque. Sobre quiénes las recibieron, los escasos testimonios existentes indican dos pautas distintas.

En 1251, el abad arrendó por seis años, a Pedro Fruchos y a su esposa, la granja de Valdefresno, aportando el cenobio la mitad de los bueyes precisos, la mitad de la simiente y «la metad del fierro por lavor de los boys». El rentero, junto a la renta — «la metat del pan e de las serondayas», se obligó a entregar cada año «tres cogetas bonas al abbat de pan et de buen vino et de pescado et de cevada para sus bestias et carnes para sus omnes», a recibir y dar de comer a los bernardos y a sus mensajeros, y a ceder a Sandoval todos los bueyes de la hacienda «este primero año que vien... para coger el pan», pues el diploma se redactó en noviembre, con los campos sembrados. Por último, si Fruchos y su mujer morían en el plazo concertado, la mitad de sus bienes pasaría al monasterio ${ }^{73}$.

En 1269 , los monjes entregaron a $\mathrm{D}$. Melén Rodríguez y a su esposa, «emprestamo por en toda vuestra vida de ambos he dos», la granja de Valdeandrino, con «los barvechos ffechos», la semilla necesaria, cuatro yuntas de bueyes y otros aperos. No se estipuló a cambio renta alguna, cediendo la hacienda «por debdo et por naturaleza que avedes con el monesterio de Sant Noval et por cremos que faredes siempre algo en el monesterio, en vida e en muerte». Los prestameros sólo aludían a posibles dádivas y a la guarda de la heredad: «et prometemos et otorgamos embona fe de guardar et ayudar et de fazer algo al monesterio en vida et en muerte, et en aquelas cosas que nos podiermos» ${ }^{74}$.

En ambos casos, las granjas se cedieron en plena producción, con los medios para que las labores prosiguiesen. Pero las diferencias son notorias. $\mathrm{El}$ arriendo a corto plazo a un cultivador, en 1251, que aceptó sufragar un yantar como signo de dependencia, difícilmente tendría continuidad conforme avanzase el siglo XIII. El aflojamiento de la demanda de labrantios, por la coyuntura depresiva, auguraba poco futuro a tales cesiones ${ }^{75}$. La

${ }^{72}$ La roturación de las «hojas» de Valdellán se produjo en 1528. En Valsemana, las «hojas de Corrales» se rompieron en 1542 y las «hojas de Hontoria y Juncosa», en 1544. AHN. Clero, leg. 2.750 y lib. 5.170.

${ }^{73}$ Castán (1981), doc. 76.

74 Castán (1981), doc. 79.

75 De hecho, hay que esperar hasta 1445 para hallar en los fondos de Sandoval un arrendamiento similar. 
entrega en préstamo por dos vidas de 1269 revela otra estrategia, no tanto por el plazo más largo o por la existencia de débitos con el prestamero, indicio precoz de apuros económicos, como por parecer aquél un hidalgo acomodado, capaz de defender Valdeandrino de usurpaciones. El tratamiento de don, la falta de derechos del monasterio a obtener parte de los bienes del matrimonio a su muerte y la ausencia de pagos asimilables al yantar, así lo indican, recordando lo que serían, en el siglo XIv, las encomiendas de heredades ${ }^{76}$.

Entregas de granjas de este tipo facilitaban su defensa, pero iban en detrimento de la economía monacal. Un tercer testimonio, respecto de una heredad, refuerza la pauta: dificultades económicas del cenobio ${ }^{77}$, modos de afrontarlas que acababan reduciendo sus ingresos, creciente participación de la nobleza local en sus rentas y un camino cada vez más expedito hacia la encomendación. En 1286, los monjes arrendaron al caballero Johan Fernández y a su mujer, por once años, «quanto eredamiento nos emos et aver devemos en Roderos et todos los fueros que nos y emos de aver de los vasallos et de la eglesia», por «mucho plaçer que recebimos de vos et por mille et dozientos morabetinos» ${ }^{78}$. Más que arrendar, lo que hicieron los monjes fue empeñar sus propiedades y rentas de Roderos, sin reservarse el dominio señorial, a cambio de una sustanciosa suma entregada previamente ${ }^{79}$. El contraste entre los plazos fijados en 1269 y en 1286 coincide con su limitación en las cesiones a la nobleza de posesiones importantes, detectada en varios monasterios, sobre todo castellanos, entre 1250 y $1400^{80}$.

En el siglo XIv, aunque faltan noticias sobre este bloque de granjas, la clave en el caso de Sandoval estaria en el avance de la encomendación. La encomienda eclesiástica adquirió un vigor nuevo en la corona castellana en ese siglo ${ }^{81}$. La creciente pugna interseñorial por un producto agrario

${ }^{76}$ Concesiones análogas se han documentado para Carracedo [Pérez-Embid (1986), 437 y ss.] y Moreruela [Alfonso (1983), 344 y ss.]. Para varios monasterios castellanos, Estepa (1993).

77 Que confirman operaciones como la permuta de «Nechas», en 1318.

78 Castán (1981), doc. 80.

${ }^{79}$ Esta cesión difiere de los «arrendamientos de bienes y vasallos con reserva de señoríom, realizados por Oña entre 1229 y 1387, pero es similar a otras verificadas por Sahagún a fines del siglo xIII. Estepa (1993), 382 y 398.

vo Estepa (1993), 408.

81 Santos Diez (1961). Era, en origen, una prerrogativa regia relacionada con la participación de los monarcas en la fundación de iglesias y monasterios, que dispensaba protección a la entidad beneficiaria. 
y una mano de obra declinantes, junto a la debilidad de la monarquía, situaron a los monasterios a la defensiva frente a la nobleza ${ }^{82}$. Muchos buscaron amparo poniendo parte de sus dominios bajo la tutela de caballeros que, no contentos sólo con el prestigio adquirido, procuraron resarcirse por otros medios ${ }^{83}$.

Para Sandoval, pese a la falta de detalles, se aprecia lo sucedido. Con los antecedentes citados de 1235, 1269 y 1286, el fenómeno se extendió por el dominio en el primer tercio del siglo XIV, según dos alusiones de 1321 y $1332^{84}$. Mediado el siglo, sería usual, a juzgar por la condición que puso el noble donante, en 1369, de la aldea de Navatexera: que Sandoval no la encomendase a nadie que no fuera él mismo o sus herederos ${ }^{85}$. Poco después se produciría la encomendación del monasterio, por entero, al duque de Benavente ${ }^{86}$. En 1380, el abad acudió a Medina del Campo y denunció ante Juan I y sus jueces oidores los estragos cometidos por el duque, afirmando que tenía al cenobio en encomienda contra su voluntad y que «echaba tributos» a sus vasallos, «constriñendo a los vecinos de Mansilla y Rueda, sus villas, a que obligasen a dichos vasallos a pagar con ellos todos los pechos» ${ }^{87}$. Los jueces dieron cuatro meses al duque para que documentase sus derechos a la encomienda y, al no comparecer, sentenciaron en su contra, ordenándole que «desamparase» a los monjes y no los molestase más ${ }^{88}$.

Esta resolución, sin embargo, no liberó del todo al dominio monacal de encomiendas nobiliarias, algunas de las cuales acabaron implicando mermas patrimoniales. Así, consta que Sandoval perdió, en la segunda mitad del siglo Xv, la jurisdicción que ostentaba sobre Villomar a manos del Almirante de Castilla, y, sobre Villamuñio, a las del conde de Grajal ${ }^{89}$. Frente 70-71.

82 Numerosas quejas de prelados aparecen ya en las cortes de 1295. Moreta (1978),

${ }^{33}$ Santos Díez (1961), 51 y ss.

*4 En 1321, los monjes amenazaron al concejo de Mansilla, en un litigio, con denunciarle a sus encomenderos. En 1332, Alfonso XI, al confirmar las exenciones fiscales de Sandoval, creyó preciso recordar la titularidad regia, en última instancia, de las encomiendas monásticas. AHN. Clero, legs. 2.744 y 2.745.

${ }^{85} \mathrm{BN}$. Manuscritos, 712, donación núm. 15.

* Acaso coincidiendo con el paso de Mansilla y Rueda, antiguas villas reales, a los dominios de dicho magnate. Mansilla.

${ }^{87}$ AHN. Clero, leg. 2.745. Recuérdese lo señalado acerca del contencioso fiscal con

\$ Sentencias análogas, que prueban lo extendido del fenómeno, se emitieron en 1380 a favor de las casas cistercienses de Bujedo, Rioseco, Carracedo y La Vega. Pérez-Embid (1986), 569-570.

${ }^{89}$ AHN. Clero, leg. 2.759. 
al conde de Valencia de Don Juan, se defendió con éxito de su intento de apropiarse, en 1486, la granja de Palacino, pero no pudo evitar perder, tras un largo contencioso resuelto en 1581 , la jurisdicción sobre parte de Fuentes de Carbajal ${ }^{90}$. Y, frente al marqués de Toral de los Guzmanes, logró recuperar Membrillar, en 1495, pero no Isoba, de la que, luego de un pleito que se alargó hasta 1539 , sólo conservó la propiedad eminente ${ }^{91}$.

Las pérdidas citadas, con todo, no parecen excesivas, aunque habría que añadir la de Villasinda, trocada por otros predios en $1439^{92}$. Las demás arribaron a la Edad Moderna en manos de los monjes, unas olvidada su condición de granjas - Payuelo, Fuentes de Carbajal y Villamoros de Ribaesla-, y otras aún como explotaciones compactas - Palacino, La Navilla, Valdeandrino, Villamor y Valdefresno-, pero ya no con el carácter de unidades orgánicas de explotación, sino con el de cotos redondos.

\subsection{Las heredades: el predominio de su cesión parcelada a largo plazo}

El cambio de coyuntura iniciado hacia 1250 también indujo transformaciones en la gestión de las demás fincas de Sandoval. En su caso, la estrategia adoptada consistiría en extender la explotación indirecta. El recurso a la mano de obra dependiente, una necesidad ineludible, debía acometerse, como dije, restando incentivos a la emigración de los cultivadores y sustituyendo las sernas por otras exacciones menos costosas para éstos. Los fondos de Sandoval aportan pocos testimonios coetáneos, pero su documentación moderna contiene suficientes noticias medievales para sostener que, en cada hacienda, los monjes dividieron en lotes los predios integrantes de la reserva, entregándolos por un canon a los campesinos, como agregados a los primitivos solares si eran vasallos, o como nuevas concesiones a individuos que pasaron a setlo. Vehículos de este proceso serían, como fórmula de cesión, el préstamo y, como figura que aglutinaba los pagos a efectuar, el fuero. Ello, en relación a las dos tendencias detec-

\$ AHN. Clero, legs. 2.741 y 2.752. Como el lugar tenía dos barrios, se asignó la jurisdicción de uno al conde, «de tejas adentro hasta salir las goteras de las casas y no más», y la del otro al cenobio.

${ }^{91}$ AHN. Clero, leg. 2.759 y carp. 1.001, dip. 21. La posesión y el señorío se otorgaron al marqués.

92 AHN. Clero, carp. 1.000 , dip. 16. Por ser poco provechosa, al estar situada en un lugar que se había despoblado. 
tadas en cesiones similares hechas por varios monasterios castellanos entre 1230 y $1380^{93}$, supone añadir una intermedia, definida por cesiones vitalicias que se perpetuarían en el siglo XIV y parte del XV, y experimentarían una profunda renovación desde 1450 , dando paso a arrendamientos renovables.

Lo primero a resaltar es la extensión del fenómeno. Desde mediados del Doscientos, según parece, afectó a 42 de las más de 60 fincas de Sandoval y a cuatro granjas. Lo segundo atañe a su cronología. Aunque existen menciones posteriores a préstamos, esta figura, como fórmula de entrega del útil de las haciendas monacales, no alcanzó la tercera década del siglo Xv: la primera concesión en préstamo documentada data de 1248 , y la última de $1413^{94}$. En las fincas de Sandoval, como en las del cabildo catedralicio de León, lindantes muchas veces, se habría instituido un sistema de préstamos desde mediados del siglo XIII que, a fines del XV, era cosa del pasado ${ }^{95}$.

$\mathrm{Al}$ efecto, un texto monacal redactado en 1491, que recoge otros más antiguos luego perdidos, resulta de interés ${ }^{96}$. En él aparecen siete heredades cedidas en préstamo sin la fecha de concesión, pudiéndose colegir ésta a partir de lo referido a dos de ellas. Así, la división en siete préstamos de la granja de Villasinda, entre otros tantos vecinos del lugar, no puede admitirse para 1491, porque los monjes se habían desprendido de ella en 1439 , ni para esta fecha, cuando la aldea llevaba tiempo yerma. Si se despobló a fines del siglo xIv o inicios del $\mathrm{xv}$, su división y cesión en préstamos debe situarse entre 1318, última fecha en que Sandoval recibió predios en el término, y dicha época.

En su caso, la mención a una extensa hacienda en Valdesaz -286 fanegas y dos estopos de labor, más 13 prados- dividida en catorce préstamos, sorprende porque, según los documentos modernos del cenobio, Sandoval nunca poseyó tanta tierra en esa aldea. Pero cobra sentido al

${ }^{93}$ Una, hacia los arrendamientos temporales a campesinos, muy frecuentes luego de 1400, y otra, hacia entregas de carácter perpetuo, quizá enfitéuticas. Estepa (1993), 407-408.

94 Véase la nota 40 y AHN. Clero, carp. 999, dip. 18. Tampoco en los dominios de Palazuelos y Valbuena se verificaron nuevas concesiones en préstamo después de 1400 . Díez Espinosa (1982), 166, y Ortega (1983), 125.

95 Sobre la gestión del patrimonio del cabildo, Fernández Flórez (1985).

96 AHN. Clero, leg. 2.760. Se trata de un prontuario de documentos, hecho ante notario. Su contenido no puede atribuirse a la fecha de redacción, como hace Pérez-Embid (1986), 405. Basta leer su encabezamiento: «Este quaderno es de mucha utilidad. Contiene diversos fracmentos de los Apeos antiguos y otras escrituras de foros, sacados de los Originales por mandado del Bachiller Corregidor de Mansilla Diego de Castrillo.» 
observar que, en 1752, el coto redondo de Palacino, apenas a un kilómetro de Valdesaz, incluía 287 fanegas de tierra y 15 de prados ${ }^{97}$. Cabe aceptar que fuese esta granja la repartida a los vecinos del lugar en préstamos, que no subsistirian en 1491 , ya que Palacino se venía arrendando desde $1445^{98}$. Dicha forma de cesión, de nuevo, no habría pervivido más allá de las primeras décadas del siglo xv. Pero, además, los fueros exigidos a los prestameros permiten situar la época en que se introdujo: la mitad se estipuló en maravedís y cornados, pieza de vellón esta última acuñada desde 1286 y muy utilizada hasta 1350, cuando empezaron a emitirse cruzados y blancas $^{99}$. Por tanto, estos indicios permiten remontar el origen de los préstamos atinentes a las heredades de Sandoval al período situado entre 1250 y 1350 .

Un tercer asunto incumbe al significado de la citada forma de cesión. El préstamo, como figura definitoria del derecho de posesión del campesino sobre las heredades anejas al solar, luego de su entrega por el dueño con retención del dominio, estaría presente en León ya en el siglo xI ${ }^{100}$. Las concesiones en préstamo efectuadas por Sandoval desde 1250 - y por otras instituciones eclesiásticas cercanas ${ }^{101}$-, implicaron el acceso de los cultivadores, de modo vitalicio, a lotes de tierra procedentes de lo que había sido la reserva, a cambio del pago de fueros, en cuyo seno las sernas desaparecieron o pasaron a ser marginales.

En principio, serían los vasallos de tales instituciones los receptores de tierras en préstamo, que engrosarian sus solares y harian aumentar los fueros que abonaban como solariegos o foreros. Pero, al ahondarse la depresión demográfica, las cesiones alcanzarian a personas ajenas a tal condición, que pasarían a pagar fuero como prestameros ${ }^{102}$. Así, dichas instituciones, gracias a la ambigua naturaleza como tributo-renta del fuero, extenderían sus redes de dependencia precisamente cuando los nobles pugnaban por

${ }^{97}$ AGS. Dirección General de Rentas, I Remesa, lib. 365, fol. 172, Respuestas Generales del Catastro.

${ }^{96}$ En 1454, dos vecinos de Grajal de Oteros la traían en arriendo desde hacía nueve años. AHN. Clero, leg. 2.741.

${ }_{99}$ Dufourcq y Gautier-Dalché (1983), 209 y 252.

${ }^{100}$ Ayala (1994), 191 y 209-210.

101 Al menos, Santo Toribio de Liébana, San Isidoro, el cabildo catedralicio, Espinareda y Sahagún. Gautier-Dalché (1965), 93-94, Estepa (1975), 98 y ss., Fernández Flórez (1985), 249 y ss., y García Gallo (1957), 370-371.

${ }_{102}$ Como en el dominio de San Isidoro de León, aunque en éste, ya en 1313, foreros y prestameros tendían a confundirse; Estepa (1975), 96. Sandoval tampoco distinguió, en 1311, cuando cedió una heredad en Villaturiel «con sus vasallos, con los prestamos y fueros pertenecientes a ella». AHN. Clero, leg. 2.750. 
despojarlas de sus vasallos. A veces, el pago complementario de un yantar despeja toda duda sobre la posición de los prestameros ${ }^{103}$.

Las condiciones exigidas a los prestameros del cabildo catedralicio leonés a fines del siglo XV muestran otros rasgos de estas concesiones, presentes también en las realizadas por Sandoval: la obligación de satisfacer cada año el fuero, la prohibición de vender, donar o trocar sin licencia los predios, la de subdividir los lotes y la vinculación entre las fincas cedidas en cada lugar y sus habitantes ${ }^{104}$. Las cesiones en préstamo, añadidas no pocas veces a los primitivos solares campesinos, permitieron la constitución de explotaciones orgánicas a escala familiar, al incluir tierras de pan llevar, suelos para la construcción de casas y otros bastimentos, prados, huertos, herrenes y pagos de viñedo ${ }^{105}$.

Los fueros que debían costear los prestatarios eran de contenido muy variado. Ello respondía a la propia evolución del fuero, que, a la contraprestación por el solar, había incorporado los pagos a satisfacer por la conmutación total o parcial de las sernas y por las cesiones en préstamo. Y a las necesidades de productos agrarios de las instituciones eclesiásticas, cuyo acopio ya no podían fiar por entero a las cosechas y esquilmos obtenidos directamente en sus dominios. Pero, pese a dicha variedad, destaca la relativa predominancia de los pagos en moneda frente a las entregas de grano.

Según el Cuadro 1, estimando la capacidad adquisitiva en grano del dinero obtenido, Sandoval habría podido adquirir 35 fanegas de pan frente a las 14 recaudadas y el cabildo 142 frente a $123^{106}$. Por tanto, la adaptación del patrimonio monacal a la crisis abierta en la economía castellana hacia 1250 entrañó un amplio proceso de cesión del usufructo de la tierra. Éste, en muchas heredades y en algunas granjas, se concretó en entregas en préstamo, concesiones vitalicias de terrenos de diverso aprovechamiento pro-

${ }^{103}$ Imposición documentada para Sandoval en 1312 y 1377. AHN. Clero, carps. 995, dip. 11, y 996, dip. 15.

104 Acceder a un préstamo en términos de una localidad concreta requería morar en ella; si un prestatario emigraba debía transferir el préstamo a otro vecino que siguiese «haciendo fuero». Obsérvese que, a fines del Cuatrocientos, el vocablo aludía más al lote cedido que a la forma de cesión. Fernández Flórez (1985), 256 y ss.

105 Según el prontuario de 1491, los siete préstamos de la granja de Villasinda incluían 64 piezas de cereal, 47 majuelos, cuatro suelos, cinco casas, seis prados, tres huertos y un palomar. Los catorce préstamos de Valdesaz y Palacino, 91 labrantíos de pan, 52 de viñedo, 13 casas, 13 prados, dos suelos y dos huertos. AHN. Clero, leg. 2.760.

${ }^{106}$ He aplicado los precios, relaciones y cambios siguientes: 10 maravedís por fanega de grano, 1,6 heminas por estopo, 3 heminas por fanega, 9 dineros por cornado, 10 cornados por maravedí y 2 blancas por maravedí. 


\section{CUADRO 1}

Dinero y grano contenidos en fueros abonados por concesiones en préstamos

\begin{tabular}{lcc}
\hline & Sandoval, c. 1286-1400 & Cabildo catedralicio de León, c. 1490 \\
\cline { 2 - 3 } Heredades sitas en..... & Siete localidades & Ocho localidades \\
Préstamos................. & 36 & 113 \\
Dinero devengado...... & 349 maravedís, 7 cornados & 1.288 maravedís y 260 \\
blancas viejas \\
Grano devengado ....... & 13 fanegas, 1 estopo y 2 cuartos & 87 heminas y 177 estopos \\
\hline
\end{tabular}

Fuentes: AHN. Clero, leg. 2.760, y Fernández Flórez (1985), 221, 222, 224, 228 y 233.

cedentes del fraccionamiento de la reserva, que permitieron a los cultivadores la formación de explotaciones orgánicas familiares. A cambio, éstos se obligaron a pagar fueros, en buena parte en moneda, expresando su condición de usufructuarios y de vasallos de la comunidad cisterciense. Los monjes lograrían, de este modo, reforzar los lazos con sus dependientes e incrementar su número. Pero dicha transformación hubo de acarrear costes considerables a la economía monástica.

Sandoval muestra indicios de una creciente debilidad durante el siglo XIv. Junto a trabas en el ejercicio de sus derechos, el cese o reducción de ciertos devengos y la pérdida de control sobre diversas porciones de su dominio, debidos a la acción de nobles y señoríos concejiles como el de Mansilla, dicho cambio en las formas de explotación, al sustituir entradas de granos por fueros en los que no abundaban, debió mermar sus ingresos en especie. Ignoro si los ingresos en dinero y el posible desarrollo de la ganadería pudieron compensar el declive de su participación en el producto agrícola, pero la propia mengua de la familia monástica hace dudarlo: la floreciente comunidad de 1235 , formada, al menos, por 25 monjes y 20 conversos, contaba sólo con 15 monjes en $1394{ }^{107}$.

La penuria de la economía monástica y la postración demográfica de su entorno tocarían fondo a fines del siglo xIv y comienzos del xv. En la gestión de las fincas apareció entonces una novedad significativa, las entregas «ad complantandum». Vigentes sólo veinte años, entre 1389 y $1410^{108}$, suponían la cesión gratuita de un terreno yermo a varios labriegos, por diez años, para que plantasen vides; acabado el plazo, el majuelo se

${ }^{107}$ AHN. Clero, carp. 997, doc. 8.

${ }^{108}$ Lapso para el que se documentan once. AHN. Clero, carps. 996, dip. 22; 998 , dips. $8,10,10$ bis, 12,21 y 23, y 999 , dips. $1,4,9$ y 15 , y leg. 2.752 . 
dividía en dos o tres partes, quedándose una la abadía y cediendo el resto en propiedad a los plantadores. Su introducción, para poner en cultivo pagos abandonados, sería un remedio extremo ante una escasísima demanda de labrantíos: sólo en esa situación los monjes aceptarian perder entre la mitad y los dos tercios de una finca a cambio de que el resto diese fruto. Una coyuntura que, en su punto culminante, favoreció la aparición de cesiones tan singulares, hubo de influir sobre los plazos de los préstamos. Establecidos originalmente por la vida del prestamero, tenderían a renovarse de inmediato a favor de sus sucesores, al acentuarse la depresión demográfica en el siglo xIv. Los plazos se fijarían por varias vidas ${ }^{109}$, o bastaría con que los herederos garantizasen el pago de los fueros para que su disfrute se perpetuase en el seno de los grupos familiares.

La desaparición de su carácter vitalicio entrañaba riesgos para un cenobio incapaz de controlar el proceso. Al pasar el tiempo, la división por herencia de las explotaciones campesinas y de los bienes usufructuados, obstaculizaría la recaudación de los fueros y podría suponer la disolución del vínculo entre tales bienes y el monasterio ${ }^{110}$. En efecto, en muchas haciendas la citada percepción resultó entorpecida, olvidándose qué bienes incluía cada cesión, y, en algunas, los préstamos desaparecieron con los prestameros. Así, en la antigua granja de Villasinda, yermo el lugar homónimo, no quedaba rastro de aquéllos en 1439. En Valdesaz, el descenso de su vecindario acabó con la explotación en préstamos de Palacino. Lo uno lo prueba el que, en 1423, dos vecinos de Gusendos aceptasen «ser vecinos y moradores en Valdesaz por ocho años y ser vasallos deste monesterio y pagarle sus fueros y derechos» ${ }^{111}$. Lo otro, el que Palacino recobrase su fisonomía de heredad unitaria, arrendándose desde 1445 .

Las demás concesiones en préstamo no sucumbieron tan rápidamente, pero llegaron al siglo XV inmersas en una notable confusión. Ésta se cifraría en un conocimiento muy imperfecto por parte de los monjes de su contenido, que habría perdido sus características primitivas incluso cuando

109 Ya en 1312, al fallecer un prestamero de Palacios de Valdellorma, los monjes renovaron la cesión a su viuda, a sus hijos y a uno de sus yernos, por las vidas de todos ellos. AHN. Clero, carp. 995, dip. 11.

${ }^{110}$ En 1262, el abad de Sahagún ya mostraba su inquietud al respecto: «Et mandamos que las heredades [de San Llorente] que las vendades unos a otros..., que non se pierda el fuero. Et en quantas partes se partiren las heredades et elos suelos, que fagades tantos fueros. Et si el suelo o heredat que fue partido del padre entre hermanos, et hermano dalguno comprar o heredar de so hermano, que faga un fuero por el». Garcia Gallo (1957), 371.

111 AHN. Clero, carp. 1.000, dip. 4, y leg. 2.752. 
los linajes usufructuarios hubiesen sobrevivido; más aún al contrario, cuando las haciendas precisasen nuevos cultivadores. En ambos casos, los fueros a satisfacer eran más fáciles de identificar que los predios en cuestión. Así las cosas, Sandoval se esforzó por aclarar qué campesinos debían pagar fuero y por hallar quien los abonase por fincas abandonadas. Los efectos de ello no tardaron en manifestarse. El préstamo perdió su significado como forma de entrega del dominio útil, designando, donde subsistió, conjuntos de bienes de incierto contenido. El fuero, junto a su sentido de tributo-renta, asumió el de modo de cesión del usufructo, y los otorgamientos a fuero, usualmente perpetuos, fueron sustituyendo a las concesiones en préstamo, aludiéndose, significativamente, a préstamos aforados ${ }^{112}$.

La recuperación demográfica del Oriente leonés, desde la cuarta década del siglo xv, acentuó el problema de la fragmentación por herencia de los patrimonios campesinos. Ante el riesgo de desintegración de los conjuntos de bienes cedidos, Sandoval exigió su transmisión indivisa de padre a hijo, iniciativa a la que el cambio de coyuntura en marcha pronto restó efectividad ${ }^{113}$. Ciertamente, ya se estaba produciendo una novedad en la década de 1430: el creciente protagonismo del grano en los pagos a efectuar, al mejorar sus términos de intercambio gracias al incipiente aumento poblacional y al erosionarse las rentas en dinero, debido a la depreciación del maravedí ${ }^{114}$.

Hacia 1450, afianzados los cambios referidos, la explotación de las heredades monásticas debía de presentar un panorama intrincado. Éste impuso a Sandoval una compleja tarea en la segunda mitad del siglo: la de reformular sus relaciones con los cultivadores para adaptar el volumen y composición de su renta feudal a las nuevas circunstancias. En la mayoría de las haciendas, se delimitaron dos esferas de actuación, ocultas durante

112 Según un precoz testimonio, de 1406, un vecino de Villamoros tomó «unos suelos para fabricar casas..., e una era a fuero con el préstamo que llaman del Palaciom, por dos gallinas y cinco maravedís anuales; AHN. Clero, carp. 998, dip. 18 bis. Otros dos ejemplos, de 1411 y 1425 , en AHN. Clero, carps. 999, dip. 16, y 1.000, dip. 5.

${ }^{13}$ Dos fueros perpetuos, suscritos en 1436, incluyeron dicha cláusula, siendo uno de ellos transferido a un solo heredero en 1445. Pero otro, concertado por dos labriegos en 1438 , había pasado a cinco de sus descendientes en 1464. AHN. Clero, carps. 1.000, dips. 12, 14,17 y $18,1.001$ y dip. 6 .

114 En 1432, Sandoval obligó al vecino de Villamoros que había aforado ciertos bienes en 1406, a trocar los cinco maravedís originales por tres fanegas de trigo; AHN. Clero, carp. 1.000, dip. 11 bis. Los dos fueros de 1436, citados en la nota anterior, lo fueron por 38 fanegas de grano y seis gallinas. Respecto al envilecimiento del maravedí, según Mackay (1980), 256, su valor expresado en plata pasó, del índice 100 en 1430, a 50 en 1450 y a 24 en 1474 . 
dos siglos dentro de las concesiones en préstamo: la de los antiguos solares campesinos y la de las heredades agregadas a ellos.

En cuanto a la primera, los monjes paliaron la desmembración de las tenencias familiares según lo previsto por el abad de Sahagún en 1262: que sobre cada elemento desgajado de aquéllas cuyo dominio directo perteneciera al cenobio, recayese el fuero consiguiente. El aforamiento perpetuo por pequeñas cantidades de dinero, gallinas, cera $u$ otros productos se afirmó sólidamente en este ámbito ${ }^{115}$. Respecto a los labrantíos, procuraron su emancipación de los vetustos préstamos, sin desligarlos, en principio, del fuero perpetuo y de los labriegos asentados en suelo del monasterio, pero exigiendo en grano las rentas forales ${ }^{116}$. Entre 1474 y 1489 , la cesión a fuero perpetuo de tres antiguas granjas, Valdeandrino, Valdefresno y La Navilla, entrañó un importante avance en este sentido ${ }^{117}$.

En 1483, el proceso había concluido en Villacontilde y Villiguer. En ese año, de un lado, seis vecinos de un lugar y cuatro del otro, eran foreros de Sandoval, abonando anualmente por cinco casas y suelos de casa, dos prados, dos herrenes y una huerta, 67 maravedís, 12 gallinas y seis «días de serna». De otro, las labranzas del cenobio en ambos términos, aforadas a dos vecinos de Villacontilde y uno de Villiguer, rendían anualmente 76 fanegas de mediado trigo y cebada y cuatro gallinas ${ }^{118}$.

Con el tiempo, el propio significado del fuero resultó afectado. En el siglo XvI, el aforamiento de haciendas, con su énfasis en la división a largo plazo entre dominio directo y útil, acabó considerándose pura enfiteusis, trocándose el término fuero por foro. En cambio, los fueros que recaían sobre las casas campesinas y sus anexos, mantuvieron el sentido de modo de cesión del usufructo adquirido en el siglo xv, sin perder el original de tributo-renta. Siglos después, el que un labriego abonase fuero a Sandoval

115 Citaré ejemplos referidos sólo a nueve lugares: otorgamientos de suelos para construir casas y otros bastimentos (1453, 1454, 1484, 1485 y 1488), prado para hacer casa (1453), casas, solas o con lagares, corrales, suelos, linares o huertos $(1461,1472,1474,1488$ y $1489)$ y huertos y palomares $(1469,1481,1475$ y 1485). Los devengos acordados sumaron 70 maravedís, dos blancas y 26 gallinas. AHN. Clero, leg. 2.760.

116 Se observan aforamientos de pequeños predios $(1447,1482,1483,1485,1488$ y $1489)$, de heredades completas $(1474,1479$ y 1483) y de suelos y casas para hacer molinos (1453, 1467 y 1481). Las rentas estipuladas sumaron 214,2 fanegas de grano y ocho gallinas. AHN. Clero, leg. 2.760.

117 AHN. Clero, legs. 2.747, 2.750 y 2.760.

$11 \%$ AHN. Clero, leg. 2.760 y lib. 5.150. 
se juzgaba demostrativo de una vinculación que trascendía la de un mero usufructuario ${ }^{119}$.

Pero los préstamos aforados no desaparecieron por completo del dominio cisterciense. Casi todos los subsistentes en el Quinientos radicaban en dos zonas, al Norte del cenobio, en el montuoso interfluvio Porma-Esla, y al Este, en el infecundo centro del interfluvio Esla-Cea, en términos donde, salvo excepción, las posesiones de Sandoval eran escasas. Ello sugiere que los monjes actuaron, al respecto, selectivamente, según la ubicación y características de las haciendas, manteniendo el statu quo allí donde, por causas naturales o por su parvedad, las transformaciones no suscitasen interés.

En suma, hacia 1480, el avance del fuero como forma de cesión del útil de las haciendas monacales sobre las concesiones en préstamo había implicado el desarrollo de tres realidades distintas: los fueros que, con los monjes, cabe llamar menudos, los fueros de beredades, pronto denominados foros, y los préstamos aforados. Sin embargo, ninguna de las tres sería la más relevante en la explotación de aquéllas en la Edad Moderna.

\section{1480-1520. LA EXCLUSIVIDAD DE LA GESTIÓN INDIRECTA Y EL PREDOMINIO DEL ARRENDAMIENTO}

La entrada de la economía de la Corona de Castilla en una fase expansiva, clara al iniciarse el último cuarto del siglo $\mathrm{xV}$, debió convencer a los bernardos de Sandoval de que entregar a fuero perpetuo sus labrantíos suponía desaprovechar una coyuntura en la que las cosechas tendían a aumentar. Por ello, dieron un paso más en la transformación de sus relaciones con los campesinos, cuya creciente demanda de tierra, al incrementarse su número, deparó una ocasión propicia. Así fue como la irrupción del arrendamiento, que permitía actualizar las rentas, se produjo en el dominio monástico hacia 1480 .

Semejante cambio no pudo ser del agrado de quienes llevaban a fuero las heredades monacales, por el previsible aumento de los devengos y de la incertidumbre sobre su disfrute. El que los monjes lograsen culminarlo en la mayoría de aquéllas en cuatro décadas, entre 1480 y 1520, dependió de su habilidad y del apoyo prestado por la nueva coyuntura. La apetencia de tierra cultivable mostrada por labriegos que, siendo vecinos de núcleos

119 A mediados del siglo xviI, un texto monacal referente a Fuentes de Carbajal decía: «Los vasallos deste lugar son solariegos porque todas las casas y posesiones pagan fuero al Monasterio». AHN. Clero, leg. 2.752. 


\section{CUADRO 2}

Rentas en grano e irrupción del arrendamiento en el dominio de Sandoval (1428-1520)

\begin{tabular}{|c|c|c|c|}
\hline Periodos & Cesiones documentadas & Acordadas en grano & Arrendamientos \\
\hline $1428-1478 \ldots \ldots \ldots \ldots \ldots \ldots$ & 25 & $11(44 \%)$ & $2(8 \%)$ \\
\hline $1479-1489 \ldots \ldots \ldots \ldots \ldots$ & 36 & $24(67 \%)$ & $19(53 \%)$ \\
\hline $1510-1520 \ldots$ & 46 & $34(74 \%)$ & $32(70 \%)$ \\
\hline $1428-1520 \ldots \ldots \ldots \ldots \ldots \ldots$ & 107 & $69(65 \%)$ & $53(50 \%)$ \\
\hline
\end{tabular}

FUENTE: AHN, Clero, legs. 2.760 y 2.750.

en que radicaban propiedades de Sandoval, no gozaban de ellas, operó en contra de los foreros del cenobio. Dicha presión permitió a los bernardos romper con el marco familiar, propio de préstamos y fueros, introduciendo cesiones individuales pero, sobre todo, entregas a mancomunidades de renteros, capaces de aplicar el trabajo preciso para ampliar las labores, sosteniendo la elevación de las rentas. Así, las relaciones de Sandoval con los cultivadores de sus predios pasaron a ordenarse a través del grupo de consortes coaligados para su labranza, cuyo techo, en cada lugar, lo determinaba la comunidad aldeana. Al mismo tiempo, los regulares extendieron otra novedad, que simplificaba notablemente el cobro de las rentas: la agrupación, en una sola escritura de cesión por localidad, de sus fincas, bajo la denominación genérica de «la heredad» ${ }^{20}$.

Los ejemplos abundan. La heredad de Cubillas, aforada a un vecino por 40 fanegas de grano en 1479, fue arrendada a tres, en 1486, por 48 fanegas. La de Villacontilde y Villiguer, aforada en 1483 por 76 fanegas de grano y cuatro gallinas, fue arrendada en 1513 a varios vecinos, que la tomaron de mancomún por 96 fanegas, 12 gallinas y dos libras de cera. La heredad de Roderos, arrendada a tres lugareños en 1479 por 56 fanegas, era cultivada por cinco en 1510 , abonando 88 . Por último, la heredad de Hostal, que tomó en renta un vecino de Roderos en 1486 por 18 fanegas de grano y dos gallinas, fue arrendada a varios consortes en 1519 por 36 fanegas ${ }^{121}$.

${ }^{120}$ De 10 arrendamientos de labrantíos documentados hasta 1489 , ocho se atuvieron a ello; entre los 27 registrados de 1510 a 1520 , la proporción se situó en 26 a uno. Y del total de 37 arriendos, 24 se acordaron con mancomunidades de vecinos de los pueblos respectivos y 13 con individuos en solitario. AHN. Clero, legs. 2.760 y 2.750.

121 Las fuentes son las citadas en la nota anterior. 
Los cambios referidos, amén de acometerse en un momento apropiado, precisaron, para consolidarse, cierto grado de consenso que redujese la resistencia campesina al aumento de la participación en las cosechas que perseguian los monjes. En aras de aquél, éstos adaptaron el aprovechamiento de sus labranzas al marco organizativo de las comunidades aldeanas. En concreto, asumieron el compromiso tácito de que la heredad situada en cada lugar, mientras las rentas se sufragasen puntualmente, se confiaría a sus vecinos, logrando éstos y sus herederos una seguridad en su disfrute que el paso al arrendamiento había hecho peligrar. Ello, en contrapartida, permitió a Sandoval abandonar definitivamente la gestión directa, alejándose de la esfera de la producción y de sus costes, y dotó de una notable estabilidad a la explotación de sus predios, característica presente hasta el fin del Antiguo Régimen.

Un entendimiento muy duradero, como prueban las cesiones posteriores a 1520. Efectivamente, partiendo de 509 escrituras de cesión localizadas para diecisiete de las más importantes haciendas de Sandoval, atinentes al período $1540-1830^{122}$, se observa, de un lado, que las ubicadas en términos poblados, once de ellas, se cedieron en exclusiva a los vecinos de las aldeas respectivas en el 90 por 100 de las escrituras, 301 de 335 , compartiendo su explotación con habitantes de otras en el 10 por $100^{123}$. De otro, que sólo los cotos redondos y predios situados en despoblado, seis a los que conciernen las 174 escrituras restantes, conocieron auténticas licitaciones por su cultivo, el cual fue rotando, según lo ofertado, entre mancomunidades de vecinos de las poblaciones limítrofes.

Importa destacar que el recurso al arrendamiento en el dominio de Sandoval desde 1480, al reconocer los monjes la preeminencia en el acceso a las fincas de los aldeanos de los lugares en cuyos términos radicaban, lejos de romper antiguas vinculaciones, las remodeló y creó otras nuevas. Las estirpes campesinas, como en el bajo medievo mediante préstamos y fueros, permanecieron ligadas a los predios monacales en los siglos modernos, pese a la aparente precariedad de los arrendamientos ${ }^{124}$.

${ }^{122}$ AHN. Clero, libs. 5.151, 5.158, 5.184, 5.196 y 5.197, y legs. 2.750-2.752, 2.754, 2.755, y 2.757-2.761.

${ }^{123}$ De las 34 escrituras que integran dicha décima parte, 24 se redactaron en el siglo xvil, cuando la mengua de las mancomunidades de arrendatarios debida al descenso demográfico obligó a completarlas con forasteros.

${ }^{124}$ Basten dos ejemplos. La familia De Nava, afincada en Cubillas, participó en trece arriendos de la heredad homónima, de 1566 a 1691. Los Melón, de Jabares, lo hicieron 
El arriendo mancomunado de numerosas heredades monásticas, bajo una sola escritura de cesión por lugar, fue una respuesta adecuada a las perspectivas de la economía castellana hacia $1480^{125}$. Permitió implicar en su explotación a más labriegos, extender el cultivo en su seno, obtener más diezmos y elevar las rentas ${ }^{126}$. Pero su introducción respondió, también, al citado compromiso que, por la tácita, asumió Sandoval. Cierto, la responsabilidad colectiva de los consortes en los pagos anuales, según la suerte que hubiese tocado a cada uno, beneficiaba a los bernardos y a los cultivadores ${ }^{127}$. Los unos, amén de la simplificación de la cobranza y el ahorro consecuente, lograron una mayor seguridad en la percepción de la renta, obviando imponderables, como la muerte de un rentero en el lapso de vigencia. Los otros consiguieron un margen de maniobra mayor a la hora de obtener moratorias en los pagos y, sobre todo, alejar de las subastas la adjudicación de los predios, llevándola al terreno de la negociación con el cenobio, ahorrando costes en términos de renta, aunque ello supuso que los monjes prestasen mucha atención a aspectos complementarios de las entregas de grano, también onerosos ${ }^{128}$.

Lo dicho no implica, por supuesto, que los cambios descritos contasen con la anuencia general de los campesinos. Al contrario, el que no afectasen a todas las fincas del cenobio indica la importancia que, al respecto, tuvieron los diversos niveles de resistencia campesina. Allí donde las comunidades aldeanas se mostraron más combativas, llegando el grado de conflicto a ser inasumible por los regulares, se evitó la implantación del arrendamiento y se transigió con el aforamiento perpetuo de las fincas, allanando su acceso a los labriegos mediante lo que cabe denominar enfiteusis mancomunada. Baste un ejemplo. La antigua granja de Valdefresno, sin vigilancia tras el fallecimiento del rentero, que la llevaba desde 1485 por 40 fanegas

en veintiún arrendamientos mancomunados de la heredad correspondiente, nada menos que entre 1547 y 1807. Las fuentes son las citadas en la nota 122.

125 Su consolidación desde entonces lo situó en el eje de la economía monástica. De 362 arriendos concertados para trece de las principales haciendas de Sandoval, de fines del siglo XV a inicios del XIX, el 87 por 100 se acordó con mancomunidades de renteros. Sebastián (1992b), 259.

${ }^{126}$ Las rentas en grano de cuatro fincas monacales, de 1479-1483 a 1510-1519, aumentaron un 42 por 100 . Las referentes a catorce, entre $1510-1540$ y $1588-1593$, crecieron un 34 por 100. Sebastián (1990), 60.

${ }^{127}$ Del siglo XVI al XIX, la distribución en suertes de ciertos labrantíos (los del coto monástico y Fuentes de Carbajal), la efectuaron los propios monjes, quedando al arbitrio de las mancomunidades la de los demás. En ambos casos, el criterio aplicado fue el del equipo de tracción de que dispusiese cada consorte. Sebastián (1992a), 90.

${ }^{128}$ Como el transporte del mismo hasta la abadía. Sebastián (1990), 70 y ss. 
anuales de grano, fue aprovechada ilícitamente por los vecinos de El Burgo, «pastando e rozando con sus ganados e cortando leña». Los monjes les denunciaron en 1488 y, aunque en el litigio posterior obtuvieron sentencia a favor, no lograron impedir nuevas intromisiones de aquéllos, que no depusieron su actitud. En 1489, la transacción se impuso. Sandoval se avino a ceder Valdefresno «a fuero e enzenso perpetuo para siempre jamas» al concejo de El Burgo, a cambio, eso sí, de un canon anual - 80 fanegas de grano- que doblaba el acordado cuatro años antes ${ }^{129}$.

\section{EPÍLOGO. LA CONSUMACIÓN DEL PROCESO EN EL SIGLO XVI}

Comenzado el Quinientos, el arrendamiento, dominante entre las formas de cesión del útil de las fincas de Sandoval, alcanzó a aquéllas todavía fieles a la gestión directa. No reiteraré su avance en las antiguas granjas ganaderas, un hecho menor frente a la entrega en renta de las heredades integrantes del coto monástico, consumación de la trayectoria iniciada a mediados del siglo xin.

Faltan noticias sobre la fecha exacta en que pasó a arrendarse lo que había sido el eje de la reserva de los bernardos, aunque puede situarse entre 1465 y 1490 , cuando se extendieron en el coto los arriendos de molinos y huertas, y acaeció, en 1486, la primera cesión conocida de un labrantío ${ }^{130}$. La entrega del antiguo «locum de Sot Noual» se efectuó en varios bloques, respetando los intereses de los habitantes de las aldeas inmediatas, cuya subsistencia dependía del laboreo del coto. Las dos heredades más importantes, la de Villaverde y la antigua granja de Mansillexa ${ }^{131}$, se dividieron en quiñones, adjudicándose respectivamente, en arrendamientos mancomunados únicos para cada una, a los vecinos de Villaverde y a los de Mansilla Mayor. Y, conviene destacarlo, así alcanzarían la desamortización de 1835 . Sobre las rentas y pagos exigidos a sus cultivadores, el ejemplo de 1581 que glosé en la introducción, atinente a la heredad de Villaverde, evidencia que el tránsito al arrendamiento del coto monástico

${ }^{129}$ AHN. Clero, leg. 2.747. Según López García (1990), 68, La Santa Espina también verificó cesiones en enfiteusis hacia 1490, para «comprometer a los miembros de ciertos concejos en la explotación de las haciendas situadas en las zonas más conflictivas del dominio».

${ }^{130}$ AHN. Clero, leg. 2.760.

131 Para éstas, las primeras entregas documentadas datan de 1511. 
no aligeró las cargas que recaían sobre los labriegos, ni dotó de mayor modernidad a la organización agrícola imperante.

Cabe concluir, pues, que la instauración de la explotación indirecta como estrategia exclusiva de gestión de las haciendas de Sandoval al inicio del Quinientos, fundó sobre nuevas bases el conjunto de relaciones que los monjes mantenían con sus cultivadores, sin que ello supusiese una relajación de los vínculos existentes, ni una reducción de los pagos a realizar, sino la remodelación de unos y otros para adecuar al antiguo señorío monástico a expectativas distintas de las vigentes en el Oriente leonés desde mediados del siglo xur. La abadía logró, de este modo, superar las dificultades del período bajomedieval y transformar su patrimonio en una sólida fuente de ingresos.

Para finalizar, conviene trascender el caso de Sandoval e ir algo más lejos. Las fincas monacales se cedieron adaptando su explotación al marco organizativo de las comunidades aldeanas, las cuales, convertidas en instancias de intermediación entre el cenobio y los cultivadores directos, hubieron de salir reforzadas del proceso. Y sospecho, aunque no sea éste el lugar de demostrarlo, que, en la misma época, tal estrategia también fue aplicada por otros grandes propietarios de la zona. Si se trató de una pauta generalizada, lo que habría que probar, el sistema agrario resultante, caracterizado por un acceso de los campesinos a la tierra relativamente seguro y por un aumento de la cohesión de las pequeñas comunidades aldeanas, limitaría los procesos de diferenciación social entre aquéllos, así como la introducción de nuevas modalidades de uso del suelo. Ello impondría un modelo de crecimiento agrario tradicional, que no registraría grandes éxitos productivos, pero que aseguraría, con la precariedad que se quiera, la subsistencia de los campesinos durante generaciones. Eso sí, con dos requisitos, correspondientes a una pluriactividad de baja intensidad: el recurso a la ganadería extensiva y a los esquilmos forestales, dependiente de vastos espacios comunales, y la presencia de una primitiva industria rural doméstica. Éstas serían, a mi juicio, las líneas maestras de la evolución del mundo rural del Oriente leonés entre los siglos XVI y XIX. 


\section{BIBLIOGRAFIA}

Aguadé Nieto, Santiago (1988): «En los origenes de una coyuntura depresiva. La crisis agraria de 1255 a 1262 en la Corona de Castilla», en AguAdÉ, Santiago: De la sociedad arcaica a la sociedad campesina en la Asturias medieval. Madrid, pp. 333-370.

AlFONSO ANTÓN, Isabel (1974): «Las sernas en León y Castilla. Contribución al estudio de las relaciones socioeconómicas en el marco del señorío medieval», Moneda y Crédito, 129, pp. 153-210.

- (1983): La colonización cisterciense en la Meseta del Duero. El ejemplo de Moreruela, 2 vols., Madrid.

- (1993): «Cistercienses y feudalismo. Notas para un debate historiográfico», en Sarasa y Serrano (eds.): Señorio y feudalismo en la Península Ibérica (siglos XIl-XIX), III, Zaragoza, pp. 11-40.

ÁlvAREZ BORGE, Ignacio (1996): Poder y relaciones sociales en Castilla en la Edad Media. Los territorios entre el Arlanzón y el Duero en los siglos X al XIV, Salamanca.

Álvarez Palenzuela, Vicente (1978): Monasterios cistercienses en Castilla (siglos XII-XIII), Valladolid.

Ayala Martínez, Carlos de (1994): «Relaciones de propiedad y estructura económica del Reino de León: los marcos de la producción agraria y el trabajo campesino (850-1230)», en VARIos Autores: El Reino de León en la Alta Edad Media, VI, León, pp. 131-408.

CASTÁn LANASPA, Guillermo (1977): «La formación y explotación del dominio del Monasterio de Villaverde de Sandoval (siglos XII-XIII)», en León y su Historia. Miscelánea Histórica, IV, León, pp. 213-319.

- (1981): Documentos del Monasterio de Villaverde de Sandoval (siglos XII-XV), Salamanca.

Dízz EsPinOSA, José Ramón (1982): Santa María de Palazuelos. Desarrollo, crisis $y$ decadencia de un dominio monástico, Valladolid.

DufourcQ, Ch.-E., y GauTtER-Dalche, J. (1983): Historia económica y social de la España cristiana en la Edad Media, Barcelona.

EsTePA DíEz, Carlos (1975): «El dominio de San Isidoro de León según el Becerro de 1313», en León y su Historia. Miscelánea Histórica, II, León, pp. 75-159.

- (1977): Estructura social de la ciudad de León (siglos XI-XIII), León.

- (1989): «Formación y consolidación del feudalismo en Castilla y León», en En torno al feudalismo bispánico. I Congreso de Estudios Medievales, Ávila, pp. 157-256.

- (1993): «Propiedad y señorío en Castilla (siglos XII-XIV)», en SARASA y SERRANo (eds.): Señorio y feudalismo en la Península Ibérica (siglos XI1-XIX), I, Zaragoza, pp. $373-425$.

Fernández Catón, José María (1978): Catálogo del Archivo Histórico Diocesano de León, I, León.

FERNÁNDEZ FlóreZ, José Antonio (1984): «El "Becerro de Presentaciones", códice 13 del Archivo de la Catedral de León», en León y su Historia. Miscelánea Histórica, V, León, pp. 262-565.

- (1985): El patrimonio del Cabildo catedralicio de León en la segunda mitad del siglo $\mathrm{XV}$, Valladolid. 
GarCía de CoRTÁzAR, José Ángel (1988): La sociedad rural en la España medieval, Madrid.

García de Valdeavellano, Luis (1955): «El Prestimonio. Contribución al estudio de las manifestaciones del feudalismo en los Reinos de León y Castilla durante la Edad Media», Anuario de Historia del Derecho Español, XXV, pp. 5-122.

- (1968): Curso de Historia de las Instituciones Españolas. De los orígenes a la Edad Media, Madrid.

Garcia Gallo, Alfonso (1957): «El hombre y la tierra en la Edad Media leonesa (el prestimonio agrario)», Revista de la Facultad de Derecho de la Universidad de Madrid, vol. I, 2, pp. 319-372. Cito por la edición facsímil, con igual paginación, de Barcelona, 1981.

GARCÍA SANZ, Ángel (1981a): «La localización de la propiedad rústica del Cabildo, del siglo xiII al xvin: algunas consideraciones», en Propiedades del cabildo segoviano, sistemas de cultivo y modos de explotación de la tierra a fines del siglo XIII, Salamanca, pp. 39-47.

- (1981b): «Cambio económico y formas de administración de la propiedad rústica del Cabildo de fines del siglo XIII a principios del XIX: una primera aproximación», en Propiedades del cabildo segoviano, sistemas de cultivo y modos de explotación de la tierra a fines del siglo XIII, Salamanca, pp. 96-107.

- (1981c): «Coyuntura agraria depresiva: un testimonio de la crisis económica castellana del siglo XII"), en Propiedades del cabildo segoviano, sistemas de cultivo $y$ modos de explotación de la tierra a fines del siglo XIII, Salamanca, pp. 87-96.

GAUTIER-DALCHÉ, Jean (1965): «Le domaine du monastère de Santo Toribio de Liébana: Formation, structure et modes d'exploitation», Anuario de Estudios Medievales, 2, pp. 66-117.

GONZÁLEZ JIMÉNEZ, Manuel (1995): «Del Duero al Guadalquivir: repoblación, despoblación y crisis en la Castilla del siglo XIII», en Despoblación y colonización del Valle del Duero, siglos vII-XX, IV Congreso de Estudios Medievales, León, pp. 210-224.

GuTIÉRREZ GONZÁleZ, José Avelino (1995): Fortificaciones y feudalismo en el origen y formación del reino leonés (siglos $I X$-XII), Valladolid.

JiMÉNEZ BlanCO, José Ignacio (1996): Privatización y apropiación de tierras municipales en la Baja Andalucia. Jerez de la Frontera, 1750-1995. Jerez de la Frontera.

Jular PÉrez-Alfaro, Cristina (1997): «Los bienes prestados: estrategias feudales de consolidación señorial», en Actas del VIII Congreso de Historia Agraria, Salamanca, pp. 295-310.

LADERO QUESADA, Miguel Ángel (1982): «Ingreso, gasto y política fiscal de la Corona de Castilla. Desde Alfonso X a Enrique III (1252-1406)», en LADERO QueSADA, Miguel Ángel: El siglo XV en Castilla. Fuentes de renta y politica fiscal, Barcelona, pp. 13-57.

López Garcia, José Miguel (1990): La transición del feudalismo al capitalismo en un señorio monástico castellano. El abadengo de La Santa Espina (1147-1835), Valladolid.

MaCkay, Angus (1980): La España de la Edad Media. De la frontera al imperio (1000-1500), Madrid.

Martín Fuertes, J. A., y Álvarez Álvarez, C. (1982): Archivo Histórico Municipal de León. Catálogo de los documentos, León. 
Martínez Sopena, Pascual (1985): La Tierra de Campos Occidental. Poblamiento, poder y comunidad del siglo $x$ al XIII, Valladolid.

- (1989): «Las pueblas reales de León y la defensa del reino en los siglos XII y xIII», en Castillos medievales del reino de León, León, pp. 113-137.

- (1995): «Repoblaciones interiores, villas nuevas de los siglos XII y XIII», en Despoblación y colonización del Valle del Duero, siglos VII-XX, IV Congreso de Estudios Medievales, León, pp. 161-187.

Moreta Velayos, Salustiano (1974): Rentas monásticas en Castilla: problemas de método, Salamanca.

- (1978): Malbechores-feudales. Violencia, antagonismos y alianzas de clase en Castilla, siglos XIII-XIV, Madrid.

Ortega GonzÁlez, María Jesús (1983): Santa Maria de Valbuena. Un monasterio cisterciense a orillas del Duero (siglos XII-XV), Valladolid.

PÉrez-EMbID, Javier (1986): El Císter en Castilla y León. Monacato y dominios rurales (siglos XII-XV), Salamanca.

Ríos Rodriguez, María Luz (1993): «Propiedad de la tierra y relaciones señoriales: el Praestimonium en Galicia», en Sarasa y Serrano (eds.): Señorio y feudalismo en la Península Ibérica (siglos XII-XIX), I, Zaragoza, pp. 197-207.

Rodríguez Fernández, Justiniano (1981): Los fueros del Reino de León, 2 vols., León.

RuIz, Teófilo F. (1981): «Expansión y crisis. La repercusión de la conquista de Sevilla en la sociedad castellana, 1248-1350», en Ruiz, Teófilo F.: Sociedad $y$ poder real en Castilla, Barcelona, pp. 11-48.

SAAVEDRA, Pegerto, y Villares, Ramón (eds.) (1991): «Introducción», en Saavedra y Villares (eds.): Señores y campesinos en la Península Ibérica, siglos XVIII-XX, I, Barcelona, pp. vii-xvii.

Santos Dízz, José Luis (1961): La encomienda de monasterios en la Corona de Castilla, Roma-Madrid.

Sebastián Amarilla, José Antonio (1990): «La renta de la tierra en León durante la Edad Moderna. Primeros resultados y algunas consideraciones a partir de fuentes monásticas», Revista de Historia Económica, 1, VIII, pp. 53-80.

- (1992a): Agricultura y rentas monásticas en tierras de León. Santa Maria de Sandoval (1167-1835), 2 vols., Madrid.

- (1992b): «Propiedad señorial, captación del producto agrario y estrategias de comercialización: el ejemplo de un monasterio leonés de comienzos del siglo XVI a 1835», Noticiario de Historia Agraria, 4, pp. 251-282.

VALDEÓN BARUQUE, Julio (1985): Crisis y recuperación (siglos XIV-XV), tomo 5 de la Historia de Castilla y León, Valladolid. 